Article

\title{
Dimethyl Ether to Olefins over Modified ZSM-5 Based Catalysts Stabilized by Hydrothermal Treatment
}

\author{
Maria Magomedova, Ekaterina Galanova, Ilya Davidov, Mikhail Afokin * and Anton Maximov
}

A.V.Topchiev Institute of Petrochemical Synthesis, RAS (TIPS RAS), 29, Leninsky Prospekt, Moscow 119991, Russia; podlesnaya@ips.ac.ru (M.M.); peresypkina_eg@ips.ac.ru (E.G.); davidov.i.a@ips.ac.ru (I.D.); max@ips.ac.ru (A.M.)

* Correspondence: m_afokin@ips.ac.ru; Tel.: +7-926-798-4429

Received: 6 May 2019; Accepted: 22 May 2019; Published: 27 May 2019

\begin{abstract}
The reaction of dimethyl ether to olefin over $\mathrm{HZSM}-5 / \mathrm{Al}_{2} \mathrm{O}_{3}$ catalysts modified by $\mathrm{Zr}$ and $\mathrm{Mg}$ and stabilized by hydrothermal treatment has been studied. Regardless of the introduction method and the nature of the metal, the dependence of the key products selectivity on X(DME) over hydrothermally treated steady-state catalysts does not change, and the experimental points are described by the same curves. Metal introduction and the corresponding changes in the acid sites distribution do not change the ratio of main reaction rates, only the absolute values of the formation rate of the products are changed. $\mathrm{Zr}$ doping leads to the greatest activity in the DME conversion due to an equable decrease in the total acidity of the sample. On the other hand, the Mg-modified sample has a higher amount of weak acid sites, which reduces activity. At low DME conversion, methanol is one of the primary reaction products which formed from DME simultaneously with propylene in alkene cycle. At high DME conversion, the methanol acts as a main reagent which leads to ethylene formation in the arene cycle. Based on the results, the role of the metal in the reaction chemistry is considered and the mechanism of product formation from DME over steady-state catalyst is proposed, which describes both the participation of DME and the methanol produced.
\end{abstract}

Keywords: DTO; kinetics of olefin synthesis; dimethyl ether; olefins; reaction mechanism; doping metals $\mathrm{Zr} ; \mathrm{Mg}$

\section{Introduction}

HZSM-5 is the general component of catalysts for olefin synthesis from oxygenates (dimethyl ether or methanol) [1]. Investigations of MTH (methanol-to-hydrocarbons) catalysts are focused on studying the effect of crystal size, the module of the HZSM-5 zeolite, binder type, dealumination degree, the presence of mesopores, and the physical chemical properties of catalyst, such as crystallinity, acidity, specific surface area, and the volume of micro- and mesopores [2-8]. The total number of works in the field of catalysts for propylene synthesis from methanol in the last 5 years has more than 200 . There are significantly fewer works for DME conversion to propylene on ZSM-5 based catalysts [9-12]. Recently, a number of new zeolite materials such as MCM-68, EU-1 have been proposed as catalysts for the DME-to-propylene reaction $[13,14]$. However, the correlation of the structural properties of the catalyst and reaction kinetics under steady state conditions in time is not clear.

Another aspect in the study of olefins synthesis reaction from oxygenates, which receives little attention in the literature, is the composition of the raw materials used. Industrial technologies of olefin production in fixed bed reactors over ZSM-5 (Methanol-to-Propylene (MTP), Lurgi and Dominant-to-Propylene (DTP), Japan Gas Corporation) provide methanol conversion to DME at the first stage and the conversion of an equilibrium mixture of DME/water/methanol (40/40/20 wt \%) to olefins at the second stage. Even so, most studies on the reaction are based on the use of methanol 
as a raw material rather than dimethyl ether or a mixture of oxygenates. Catalytic activity tests, in most cases, are performed using fresh catalysts at raw material conversion near to $100 \%[15,16]$. The selectivity of product formation was estimated for fresh catalyst at zero time on stream (i.e., initial selectivity) $[4,17,18]$. However, the activity of the fresh catalyst that is estimated based on conversion of raw material to hydrocarbons, decreases during the reaction due to blocking of Brønsted acid sites by coke. This also leads to altered product selectivity. On the other hand, for industrial application, a catalyst that is stable in time on stream is required. The stable state catalyst is partially deactivated and its main property is the ability to provide steady production and consumption of primary HCP (hydrocarbon pool) species: coke precursors according to a dual-cycle mechanism [19-21]. According to modern concepts, these intermediates formed with the participation of Brønsted acid sites [22,23], and at first initiate the arene cycle, ensuring the synthesis of ethylene. The role of both cycles on a stable state catalyst depending on the conversion of DME has not yet been studied in detail: there are few investigations with stable catalyst at constant conversion only [24-26]. Detailed research into the chemistry over a partially deactivated and stable catalyst will allow development of a kinetic model and simulate the industrial reactor with the modification of the well-known lump models approaches $[27,28]$.

One of the main ways to influence activity and selectivity of zeolite-based catalysts of the oxygenate conversion is their modification. The HZSM-5 zeolite can be doped with elements-such as B [17,29], P [18,30], alkaline earth metals (Mg [31-33], Ca [15], Sr, and Ba [34]), and rare metals (La and $\mathrm{Zr}[16,35,36])$ - to increase the efficiency of the process. The chemical effect of modification for fresh samples consists of changing the acidity of the catalyst and the ratio of weak and strong Brönsted acid sites. For example, modification by boron led to increased weak acid sites, efficiently avoiding hydride transfer and cyclization reactions. This decreased aromatic and coke formation [29]. Doping by phosphorous also reduced the density and strength of the acid sites of zeolite [37]. Here, increasing phosphorous content in the catalyst led to decreasing activity [18]. Calcium addition increased both the catalytic stability and selectivity of light olefins due to the formation of acid-base centers such as Ca-OH ${ }^{+}$[15]. Zirconium may also provide weak acid sites on the HZSM-5 surface, facilitating alkane isomerization [36]. Thus, for all studied HZSM-5 catalysts, the relationship of physical and catalytic properties is described by the formula: 'zeolite module (acidity) - coke content-activity'. A decrease in acidity led to a decrease in the rate of coke content on the zeolite surface and an increase in catalyst lifetime [9]. The influence of the nature of the metal on the mechanism features is poorly understood for steady state catalysts.

In this paper, we present the original kinetic data for olefin synthesis from DME over ZSM-5 zeolite catalysts with low $\mathrm{SiO}_{2} / \mathrm{Al}_{2} \mathrm{O}_{3}$ that is stable at time on stream and contains zirconium and magnesium. The stabilization of catalysts was achieved using hydrothermal treatment $[7,26,38]$ as it is the simplest and the most industrially available method of zeolite dealumination in comparison with acids, solvents, and alkalis treatment [39-41]. In this case, the conversion of DME is kept constant for a long time. The role of additives to ZSM- 5 after hydrothermal treatment in the reaction chemistry at steady-state catalysts has been considered. Zirconium and magnesium are selected as modifying metals, as they can have opposite effects on the strength and distribution of acid sites on the zeolite surface for the fresh catalysts. In particular, magnesium can convert the Brønsted strong acid sites into weak acid sites such as $\mathrm{Mg}-\mathrm{OH}^{+}$and medium acid sites that facilitate the yield of propylene by decreasing H-transfer reactions [42]. On the other hand, zirconium forms strong acid sites, favoring the oligomerization and isomerization of alkanes, and alkylation of aromatic compounds [43]. Based on these results, the routes of olefin synthesis from DME in the presence of a steady-state catalyst are suggested. 


\section{Results and Discussion}

\subsection{Characterization of $\mathrm{HZSM}-5 / \mathrm{Al}_{2} \mathrm{O}_{3}, \mathrm{Zr}$-, and $\mathrm{Mg}$-Modified Catalyst}

Metal-doped catalysts were synthesized, using a wetness impregnation method from aqueous solutions of $\mathrm{ZrO}\left(\mathrm{NO}_{3}\right)_{2}$ or $\mathrm{Mg}\left(\mathrm{NO}_{3}\right)_{2}$, followed by drying and calcination at $550{ }^{\circ} \mathrm{C}$. The samples were treated with steam. Treated samples were characterized using various physical methods such as elemental analysis, X-ray diffraction (XRD), ${ }^{27}$ Al MAS NMR spectroscopy, $\mathrm{N}_{2}$ adsorption, and $\mathrm{NH}_{3}$ thermally programmed desorption (TPD). All presented data were received for steam-treated samples.

Elemental composition, obtained from X-ray fluorescence analysis, is presented in Table 1. The determined metal loadings for modified samples reached 1.0-1.2 wt \%, in accordance with the expected nominal method content.

Table 1. Elemental composition for $\mathrm{HZSM}-5 / \mathrm{Al}_{2} \mathrm{O}_{3}$ material and $\mathrm{Zr}$ - and $\mathrm{Mg}$ - modified samples.

\begin{tabular}{ccccccc}
\hline \multirow{2}{*}{ № } & \multirow{2}{*}{ Sample } & \multicolumn{5}{c}{ Elemental Composition, wt \% } \\
\cline { 3 - 6 } & & $\mathbf{S i}$ & $\mathbf{A l}$ & $\mathbf{Z r}$ & $\mathbf{M g}$ & $\mathbf{N a}$ \\
\hline 1 & $\mathrm{HZSM}-5 / \mathrm{Al}_{2} \mathrm{O}_{3}$ & $28.77 \pm 0.11$ & $19.85 \pm 0.13$ & $0.06 \pm 0.005$ & $0.11 \pm 0.006$ & $0.03 \pm 0.012$ \\
2 & $\mathrm{Zr}-\mathrm{HZSM}-5 / \mathrm{Al}_{2} \mathrm{O}_{3}$ & $28.13 \pm 0.11$ & $19.91 \pm 0.13$ & $1.19 \pm 0.05$ & $0.10 \pm 0.006$ & $0.03 \pm 0.012$ \\
3 & $\mathrm{Mg}-\mathrm{HZSM}-5 / \mathrm{Al}_{2} \mathrm{O}_{3}$ & $29.20 \pm 0.11$ & $18.66 \pm 0.13$ & $0.02 \pm 0.002$ & $1.03 \pm 0.04$ & $0.03 \pm 0.013$ \\
\hline
\end{tabular}

According to XRD patterns (Figure 1), all samples exhibit peaks typical of $\mathrm{HZSM}-5$ and $\mathrm{Al}_{2} \mathrm{O}_{3}$ structures, suggesting that metal loading by wetness impregnation had little impact on the parent structure of zeolite. The relative crystallinity of $\mathrm{Zr}$ - and $\mathrm{Mg}$-modified samples is slightly inferior to that for $\mathrm{HZSM}-5 / \mathrm{Al}_{2} \mathrm{O}_{3}$ and reaches 95-96\%. The unit cell parameters is presented in Table S1. The difference in its values for investigated samples is less than $0.3 \%$. No distinct peaks for $\mathrm{ZrO}_{2}$ $\left(2 \theta=30-36^{\circ}, 50-64^{\circ}\right)$ and $\mathrm{MgO}\left(2 \theta=30-45^{\circ}, 62^{\circ}\right)$ were observed, possibly due to the low sensitivity of the applied method to samples with low metal concentrations. However, it may also be caused by fine dispersion of $\mathrm{Zr}$ and $\mathrm{Mg}$ particles [44] or the amorphous state of oxides [45].

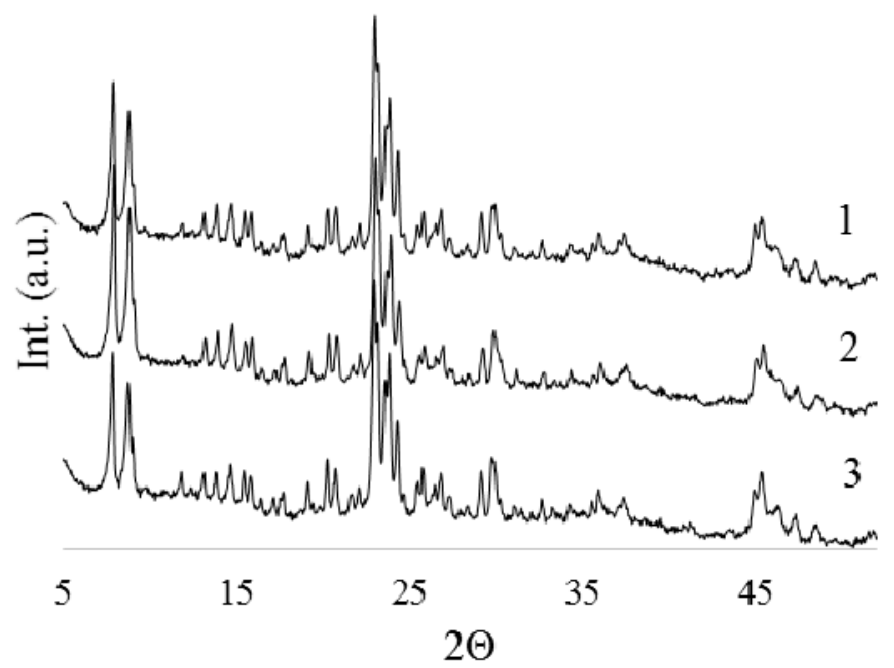

Figure 1. XRD patterns for $\mathrm{HZSM}-5 / \mathrm{Al}_{2} \mathrm{O}_{3}, \mathrm{Zr}$ - and Mg-modified samples. 1- $\mathrm{HZSM}-5 / \mathrm{Al}_{2} \mathrm{O}_{3}$; 2- Zr-HZSM-5/ $/ \mathrm{Al}_{2} \mathrm{O}_{3} ; 3-\mathrm{Mg}-\mathrm{HZSM}-5 / \mathrm{Al}_{2} \mathrm{O}_{3}$.

Figure 2 shows ${ }^{27} \mathrm{Al}$ MAS NMR spectra for $\mathrm{HZSM}-5 / \mathrm{Al}_{2} \mathrm{O}_{3}, \mathrm{Zr}$ - and $\mathrm{Mg}$-modified samples. There are three peaks characterizing the different states of aluminium in the structure of catalytic system. Two peaks with chemical shifts near 9.5 and 68 ppm can be assigned to the octa- and tetrahedral framework of $\mathrm{Al}^{3+}$ and are typically observed for $\mathrm{Al}_{2} \mathrm{O}_{3}$, but not presented in the spectrum for the catalyst HZSM-5 without binder (Figure 2, sample 0). After hydrothermal treatment, the signal intensity at $68 \mathrm{ppm}$ 
decreased along with gradual dealumination of zeolite (Figure S3). The peak with a chemical shift of approximately $55.5 \mathrm{ppm}$ is related to the tetrahedral $\mathrm{Al}$ in the zeolite HZSM-5 [7]. The weak peak at $0 \mathrm{ppm}$, assigned to the octahedral $\mathrm{Al}$ extra-framework in the mixed oxide, is observed only in the spectrum of the sample without binder. In other cases, it joins together with the peak from $\mathrm{Al}_{2} \mathrm{O}_{3}$. Comparison of spectra for samples 1, 2, and 3 suggests that catalyst modification does not lead to changes in the surrounding aluminium, either in the zeolite structure or in the binder structure.

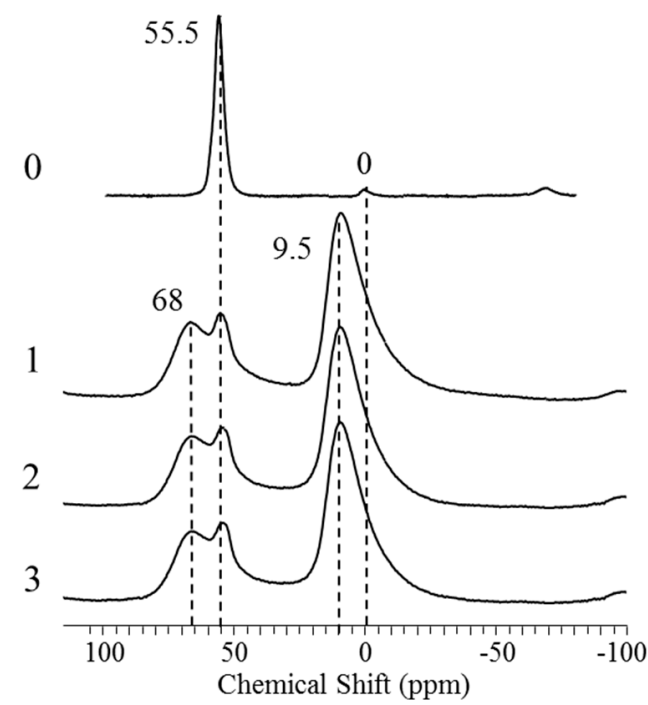

Figure 2. ${ }^{27} \mathrm{Al}$ MAS NMR spectra for $\mathrm{HZSM}-5 / \mathrm{Al}_{2} \mathrm{O}_{3}, \mathrm{Zr}-$, and $\mathrm{Mg}$-modified samples. 0-zeolite HZSM-5; 1 - HZSM-5/ $/ \mathrm{Al}_{2} \mathrm{O}_{3} ; 2-\mathrm{Zr}-\mathrm{HZSM}-5 / \mathrm{Al}_{2} \mathrm{O}_{3} ; 3-\mathrm{Mg}-\mathrm{HZSM}-5 / \mathrm{Al}_{2} \mathrm{O}_{3}$.

Table 2 lists the textural properties of samples. Size distribution and BET isotherms are shown in Figure S4. The micro- and mesopores were calculated using T-plot and BJH method respectively. As a rule, metal doping of ZSM-5 zeolite results in a volume decrease for micro- and mesopores [16,33], possibly due to the metal particles that are mostly localized in the depth of the pores. In our case, modification by $\mathrm{Zr}$ does not change the textural properties of $\mathrm{HZSM}-5 / \mathrm{Al}_{2} \mathrm{O}_{3}$. At the same time, modification, by Mg significantly changes the volume of both micro- and mesopores (by 20-25\%) with a slight change in the total specific surface area (by $9 \%$ ). This phenomenon can be explained by the high ability of magnesium to adsorb water during hydrothermal treatment and, as a consequence, to additionally change the catalyst structure.

Table 2. Textural properties of the $\mathrm{HZSM}-5 / \mathrm{Al}_{2} \mathrm{O}_{3}, \mathrm{Zr}-$, and $\mathrm{Mg}$ - modified samples.

\begin{tabular}{cccccc}
\hline \multirow{2}{*}{ № } & \multirow{2}{*}{ Sample } & \multicolumn{3}{c}{$\mathbf{S}_{\text {BET, }} \mathbf{~ m}^{\mathbf{2}} / \mathbf{g}$} & \multicolumn{3}{c}{$\mathbf{V}_{\text {pore, }} \mathbf{c m}^{\mathbf{3}} / \mathbf{g}$} \\
\cline { 3 - 6 } & & Total & Total & Micro & Meso \\
\hline 1 & $\mathrm{HZSM}-5 / \mathrm{Al}_{2} \mathrm{O}_{3}$ & 293 & 0.198 & 0.057 & 0.142 \\
2 & $\mathrm{Zr}-\mathrm{HZSM}-5 / \mathrm{Al}_{2} \mathrm{O}_{3}$ & 276 & 0.197 & 0.056 & 0.141 \\
3 & $\mathrm{Mg}-\mathrm{HZSM}-5 / \mathrm{Al}_{2} \mathrm{O}_{3}$ & 267 & 0.247 & 0.067 & 0.181 \\
\hline
\end{tabular}

The $\mathrm{NH}_{3}$ desorption profiles of $\mathrm{HZSM}-5 / \mathrm{Al}_{2} \mathrm{O}_{3}, \mathrm{Zr}-$, and Mg-modified samples after steam treatment are shown in Figure 3. It should be noted, that the acidity determined by the Temperature Programmed Desorption of $\mathrm{NH}_{3}\left(\mathrm{TPD} \mathrm{NH}_{3}\right)$ can be overestimated; however, these values can be compared with each other with a high degree of confidence. For parent hydrothermal treatment HZSM-5 $/ \mathrm{Al}_{2} \mathrm{O}_{3}$ there are two peaks at 200 and $400{ }^{\circ} \mathrm{C}$ which can be reasonably ascribed to weak and strong acidic sites, respectively. After impregnation of zirconium and hydrothermal treatment, the intensity of the low- and high-temperature peaks was decreased while the maximum temperatures were kept unchanged. The total acidity of $\mathrm{Zr}$-modified sample comparing to $\mathrm{HZSM}-5 / \mathrm{Al}_{2} \mathrm{O}_{3}$ decreased 
from 495 to $397 \mu \mathrm{mol} \mathrm{NH} / \mathrm{g}$, in agreement with published results [36]. Therefore, one may conclude, that in catalyst after steam treatment, the zirconium is regularly distributed on the zeolite surface and overlaps the acid sites of zeolite without increasing the ratio of strong acid sites.

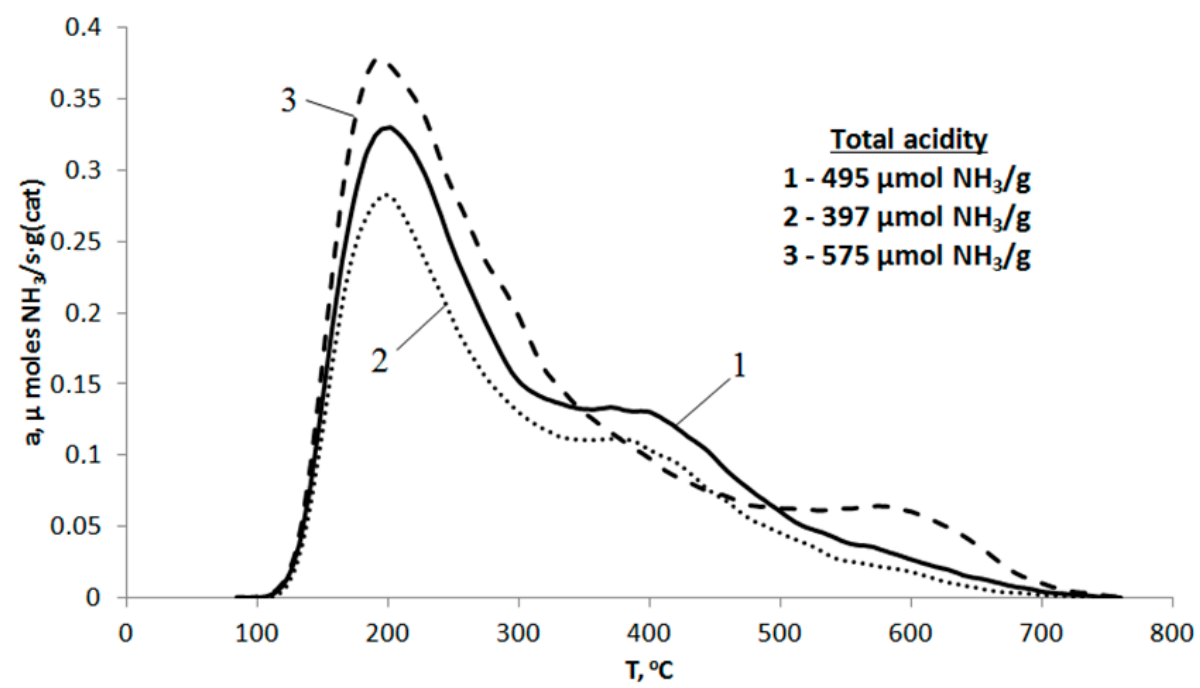

Figure 3. $\mathrm{NH}_{3}$ TPD profiles of hydrothermally treated $\mathrm{HZSM}-5 / \mathrm{Al}_{2} \mathrm{O}_{3}, \mathrm{Zr}-$, and Mg-modified samples. $1-\mathrm{HZSM}-5 / \mathrm{Al}_{2} \mathrm{O}_{3}, 2-\mathrm{Zr}-\mathrm{HZSM}-5 / \mathrm{Al}_{2} \mathrm{O}_{3}, 3-\mathrm{Mg}-\mathrm{HZSM}-5 / \mathrm{Al}_{2} \mathrm{O}_{3}$.

In contrast, for Mg-modified sample, the reconfiguration of acid sites strength towards weak sites and an increasing total acidity to $575 \mu \mathrm{mol} \mathrm{NH} / \mathrm{g}$ were observed. The results obtained are consistent with $[17,33]$ and can be explained by replacing strong acid sites on the zeolite surface of $\mathrm{HZSM}-5 / \mathrm{Al}_{2} \mathrm{O}_{3}$ with weak sites such as ZO-Mg-OH. Moreover, the TPD profile of Mg-HZSM-5/ $\mathrm{Al}_{2} \mathrm{O}_{3}$ has a peak at $500-700{ }^{\circ} \mathrm{C}$. This could be related to the desorption of $\mathrm{NH}_{3}$, adsorbed on strong acid sites such $\mathrm{O}^{2-}$ ions (low-coordination anions) present on the $\mathrm{MgO}$ surface [46,47].

A distribution of acid site strength is present in Table 3 and Figure S5. As seen, the main contribution to the total acidity for samples is made by weak acid sites, which increases as follows: $2<1<3$.

Table 3. Acidic properties of $\mathrm{HZSM}-5 / \mathrm{Al}_{2} \mathrm{O}_{3}, \mathrm{Zr}$-, and Mg- modified samples.

\begin{tabular}{|c|c|c|c|c|c|c|}
\hline \multirow{3}{*}{ № } & \multirow{3}{*}{ Sample } & \multicolumn{4}{|c|}{ Acidity of Fresh Catalyst, $\mu \mathrm{mol} \mathrm{NH}_{3} / \mathrm{g}$ (cat) } & \multirow{3}{*}{$\mathrm{B} / \mathrm{L}^{*}$} \\
\hline & & \multirow{2}{*}{ Total } & \multirow{2}{*}{$\begin{array}{c}\text { Weak Sites } \\
\mathrm{T}_{1}=200^{\circ} \mathrm{C}\end{array}$} & \multicolumn{2}{|c|}{ Strong Sites } & \\
\hline & & & & $\mathrm{T}_{2}=400^{\circ} \mathrm{C}$ & $\mathrm{T}_{3}=600{ }^{\circ} \mathrm{C}$ & \\
\hline 1 & HZSM-5/ $\mathrm{Al}_{2} \mathrm{O}_{3}$ & 495 & $337(68.1 \%)$ & $138(27.9 \%)$ & $20(4.0 \%)$ & 0.42 \\
\hline 2 & $\mathrm{Zr}-\mathrm{HZSM}-5 / \mathrm{Al}_{2} \mathrm{O}_{3}$ & 397 & $280(70.5 \%)$ & $105(26.4 \%)$ & $12(3.0 \%)$ & 0.34 \\
\hline 3 & $\mathrm{Mg}-\mathrm{HZSM}-5 / \mathrm{Al}_{2} \mathrm{O}_{3}$ & 575 & $390(67.8 \%)$ & $131(22.8 \%)$ & $54(9.4 \%)$ & 0.16 \\
\hline
\end{tabular}

\subsection{DME Conversion to Olefin}

The chemistry of DME conversion to olefin was studied over stable state catalysts after its operation on stream for at least $1 \mathrm{~h}$ (Figure S2).

Figure 4 shows the conversion of DME as a function of the specific contact time for the $\mathrm{HZSM}-5 / \mathrm{Al}_{2} \mathrm{O}_{3}, \mathrm{Zr}-$, and Mg-modified samples at a temperature of $320{ }^{\circ} \mathrm{C}$. 


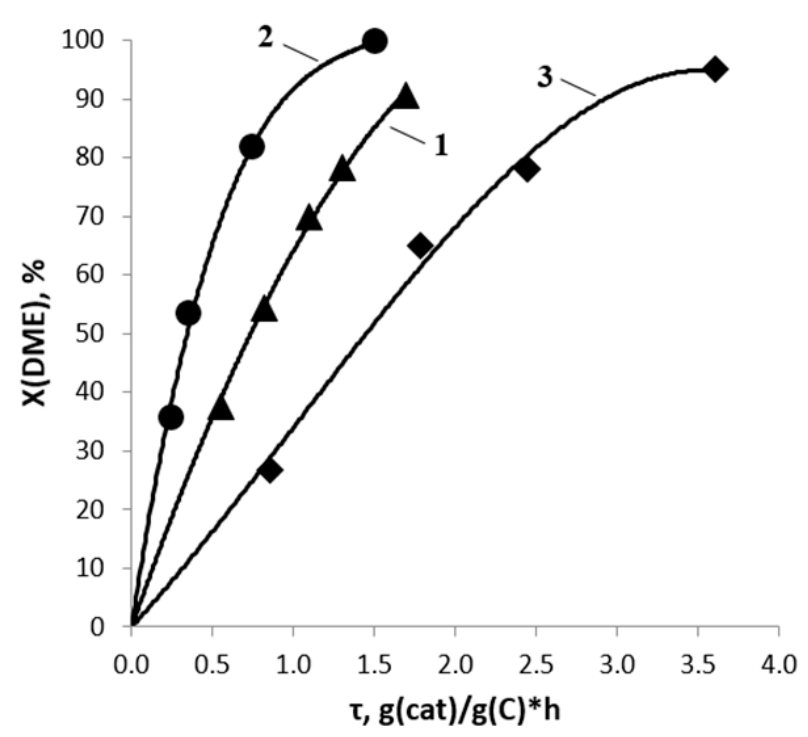

Figure 4. Conversion of DME (X (DME), \%) as a function of specific contact time $\left(\tau, \mathrm{g}(\mathrm{cat}) / \mathrm{g}(\mathrm{C})^{*} \mathrm{~h}\right)$. 1 - HZSM-5 $/ \mathrm{Al}_{2} \mathrm{O}_{3} ; 2$ - Zr- HZSM-5/ $/ \mathrm{Al}_{2} \mathrm{O}_{3} ; 3-\mathrm{Mg}-\mathrm{HZSM}-5 / \mathrm{Al}_{2} \mathrm{O}_{3}$.

As seen, the activity of the catalysts synthesized using hydrothermal treatment increases in the following order: $\mathrm{Mg}-\mathrm{HZSM}-5 / \mathrm{Al}_{2} \mathrm{O}_{3}<\mathrm{HZSM}-5 / \mathrm{Al}_{2} \mathrm{O}_{3}<\mathrm{Zr}-\mathrm{HZSM}-5 / \mathrm{Al}_{2} \mathrm{O}_{3}$. At a contact time of $1.0 \mathrm{~g}(\mathrm{cat}) / \mathrm{g}(\mathrm{C})^{*} \mathrm{~h}$ conversion of DME reaches 30,55 , and $80 \%$ respectively. These results are in contrast with the initial total acidity of the samples (Table 3): an increase in acidity due to the weak acid sites leads to a decrease in catalytic activity. It should be noted that for fresh samples of catalyst, as a rule, a direct correlation of total acidity and activity is observed [18,48]. The contradiction of the obtained results and the literature data is likely associated with the preliminary hydrothermal treatment of catalysts necessary for stabilization of the catalytic system, lowering the total acidity and ratio strong acid sites to weak sites. It is likely that an optimal ratio of strong acid sites to weak acid sites and B/L sites with quite low acidity is needed for high activity of hydrothermally treated catalysts.

Figure 5 shows the dependences of methanol, propylene, and ethylene yields as a function of specific contact time. Methanol was a main reaction product at incomplete DME conversion. Its occurrence among the reaction products was first noted in 1977 by C.D. Chang and A.J. Silvestry [49] during DME conversion over HZSM-5. However, in recent works the common conversion of sum oxygenates (DME and Methanol) based on total carbon transformation in feedstock is considered. The relationship between the yield of olefins, methanol, and the conversion of DME is not considered. Although it was shown in $[17,20,50]$ that at low DME conversion methanol is an important product that can largely determine the route of the reaction.

Modification of the zeolite with metal significantly affects the rate of methanol formation, which is apparently determined by both the total acidity and the ratio of the medium and strong acid sites. For samples with the highest activity $\left(\mathrm{Zr}-\mathrm{HZSM}-5 / \mathrm{Al}_{2} \mathrm{O}_{3}\right)$ the yield of methanol increases rapidly. It reaches a maximum of $22-24 \mathrm{~mol} \%$ at a contact time of approximately $0.6 \mathrm{~g}(\mathrm{cat}) / \mathrm{g}(\mathrm{C})^{*} \mathrm{~h}$ and then abruptly falls to almost zero. For $\mathrm{HZSM}-5 / \mathrm{Al}_{2} \mathrm{O}_{3}$, which has less activity, the same curve can be noted, but for this sample the rate of formation and consumption of methanol is lower and the yield maximum is observed at a contact time of $0.9 \mathrm{~g}(\mathrm{cat}) / \mathrm{g}(\mathrm{C})^{*} \mathrm{~h}$. For $\mathrm{Mg}-\mathrm{HZSM}-5 / \mathrm{Al}_{2} \mathrm{O}_{3}$ with the lowest activity, the reaction rate of methanol conversion is also lowest, and its curve is stretched along to the contact time axis.

The dependencies of propylene yield as a function of contact time and the pattern of change on the 'activity-acidity' parameter also have extreme character. Its yield reaches a maximum of $10-11 \mathrm{~mol} \%$ for all samples, but at a different contact time: $0.8,1.4$, and $2.7 \mathrm{~g}(\mathrm{cat}) / \mathrm{g}(\mathrm{C})^{*} \mathrm{~h}$ for $\mathrm{Zr}$-modified, $\mathrm{HZSM}-5 / \mathrm{Al}_{2} \mathrm{O}_{3}$, and Mg-modified samples respectively. 


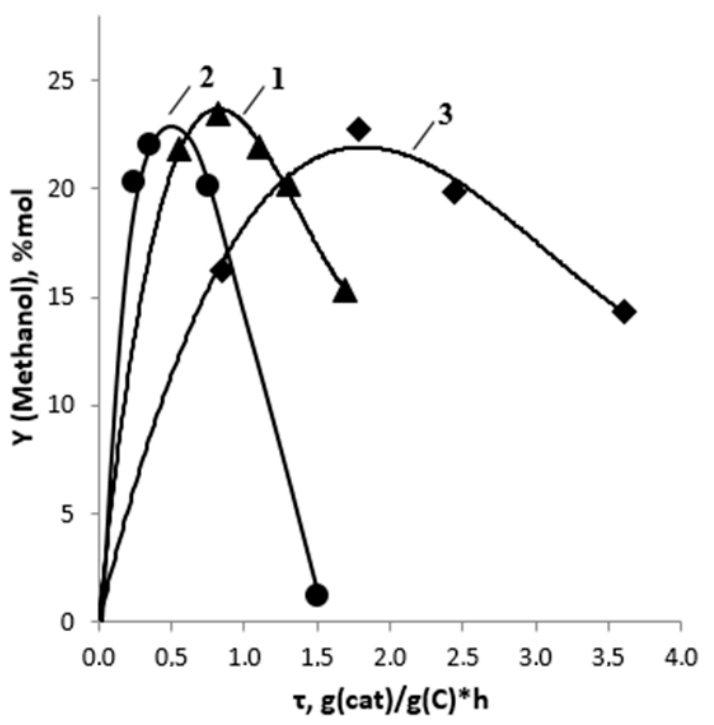

A)

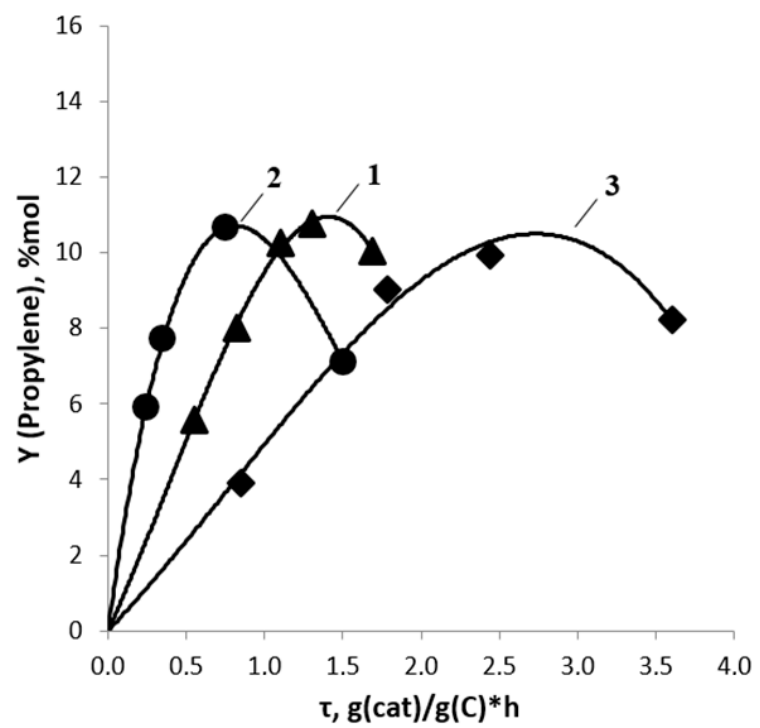

B)

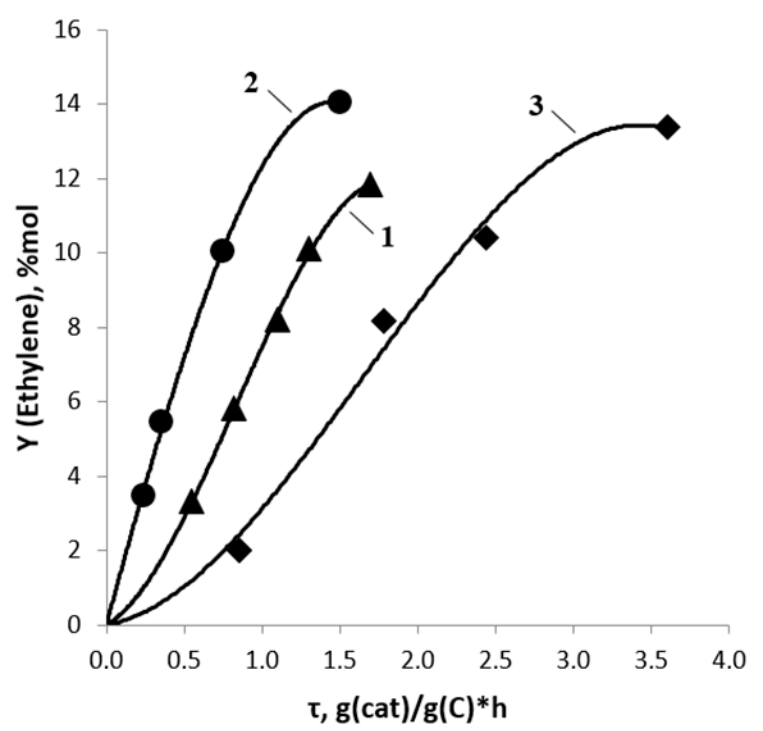

C)

Figure 5. Product yields $(\mathrm{Y}, \mathrm{mol} \%)$ as a function of specific contact time $\left(\tau, \mathrm{g}(\mathrm{cat}) / \mathrm{g}(\mathrm{C})^{*} \mathrm{~h}\right)$. 1-HZSM-5/ $/ \mathrm{Al}_{2} \mathrm{O}_{3} ; 2-\mathrm{Zr}-\mathrm{HZSM}-5 / \mathrm{Al}_{2} \mathrm{O}_{3} ; 3-\mathrm{Mg}-\mathrm{HZSM}-5 / \mathrm{Al}_{2} \mathrm{O}_{3}$. (A) methanol; (B) propylene; (C) ethylene.

Similar dependencies of methanol and propylene yields on contact time suggest that the mechanisms of their formation are similar. They are both formed rapidly and are readily involved in the secondary reactions: methylation, H-transfer, and oligomerization. The shift in propylene yield maximum relative to methanol along the contact time axis suggests that the rate of propylene production at moderate DME conversions is higher than the rate of its consumption.

The dependence of ethylene yield as a function of contact time shows nonlinear monotonic growth (Figure 5C) from 0 to $12-14 \mathrm{~mol} \%$ This growth is significantly slower than for methanol or propylene. For highly active $\mathrm{Zr}$-modified samples, the ethylene yield increased fast enough, compared to other catalysts, but growth is still slower than that for methanol yield. For a less active Mg-modified sample, ethylene production rate is the lowest, and the $Y=f(\tau)$ dependence has an S-shaped appearance, which may indicate the presence of an induction period at the beginning of the process. Thus, according to 
the observed dependence, ethylene is the final product and does not undergo any secondary reaction due to its low reactivity [51,52].

The correct comparison of the samples with significant differences in catalytic activities and the estimation of the metal modification effect can be performed at equal DME conversion. The corresponding dependencies of the product selectivity as a function of DME conversion are shown in Figure 6.

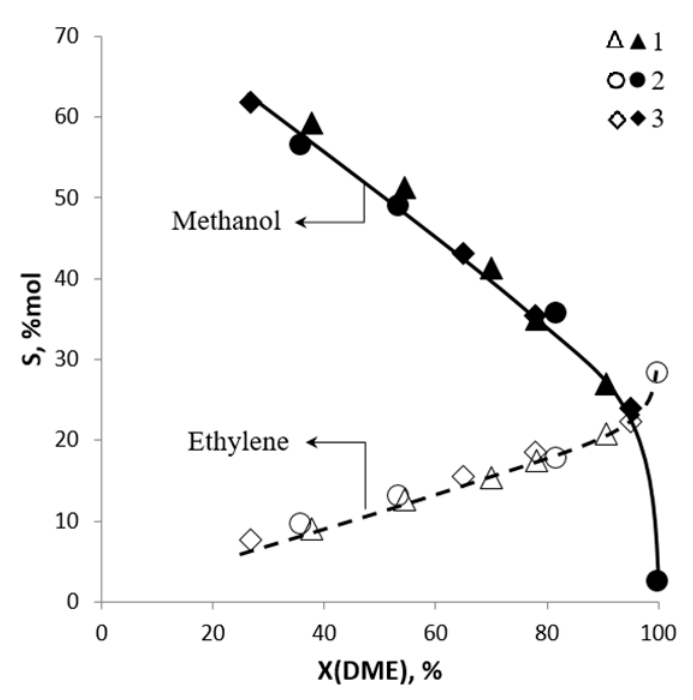

A)

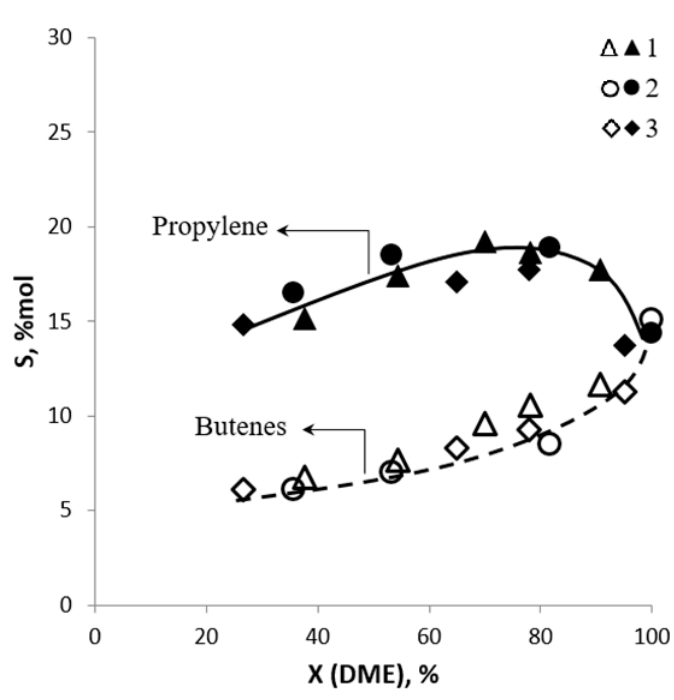

B)

Figure 6. Product selectivity (S, mol \%) as a function of DME conversion (X (DME), \%). 1-HZSM-5/ $/ \mathrm{Al}_{2} \mathrm{O}_{3}, 2-\mathrm{Zr}-\mathrm{HZSM}-5 / \mathrm{Al}_{2} \mathrm{O}_{3}, 3-\mathrm{Mg}-\mathrm{HZSM}-5 / \mathrm{Al}_{2} \mathrm{O}_{3}$. (A) methanol (solid line) and ethylene (dashed line); (B) propylene (solid line) and butenes (dashed line).

Regardless of catalyst, the selectivity on methanol decreased fast enough from $65 \mathrm{~mol} \%$ to zero in the range of DME conversion of $25-100 \%$. The opposite tendency was observed for ethylene selectivity: it increased rapidly from 2 to $28 \mathrm{~mol} \%$ in the same range of DME conversion. The selectivity of propylene and butenes slightly increased (by 3-5 mol \%) with the increase in DME conversion up to $80 \%$. The total distribution of products with DME conversion of 55 and $78 \%$ for $\mathrm{HZSM}-5 / \mathrm{Al}_{2} \mathrm{O}_{3}$ is presented in Table 4. For all investigated samples, the distribution of products is presented in Table S2.

Table 4. Product distribution for $\mathrm{HZSM}-5 / \mathrm{Al}_{2} \mathrm{O}_{3}$.

\begin{tabular}{ccc}
\hline \multirow{2}{*}{ Product } & \multicolumn{2}{c}{$\mathbf{S}, \mathbf{m o l} \%$} \\
\cline { 2 - 3 } & $\mathbf{X}=\mathbf{5 5} \%$ & $\mathbf{X}=\mathbf{7 8} \%$ \\
\hline $\mathrm{CH}_{3} \mathrm{OH}$ & 51.2 & 38.0 \\
$\mathrm{C}_{2} \mathrm{H}_{4}$ & 12.7 & 17.5 \\
$\mathrm{C}_{3} \mathrm{H}_{6}$ & 17.4 & 18.6 \\
$\Sigma \mathrm{C}_{4} \mathrm{H}_{8}$ & 7.7 & 10.5 \\
$\Sigma \mathrm{C}_{5} \mathrm{H}_{10}$ & 0.9 & 1.2 \\
$\mathrm{CH}_{4}$ & 0.5 & 0.6 \\
$\mathrm{C}_{2} \mathrm{H}_{6}$ & 0.1 & 0.1 \\
$\mathrm{C}_{3} \mathrm{H}_{8}$ & 0.3 & 0.8 \\
$\Sigma \mathrm{C}_{4} \mathrm{H}_{10}$ & 1.0 & 2.7 \\
$\Sigma \mathrm{C}_{5} \mathrm{H}_{12}$ & 0.5 & 1.3 \\
$\Sigma \mathrm{C}_{6}$ & 2.8 & 3.2 \\
$\Sigma \mathrm{C}_{7+}$ & 5.0 & 5.5 \\
\hline
\end{tabular}


Graphical extrapolation of the results to zero DME conversion suggests methanol and propylene as main primary products, whose selectivity can be 70 and $12 \mathrm{~mol} \%$, correspondingly. Butenes are formed with less selectivity, at $6 \mathrm{~mol} \%$. The ethylene selectivity tends to zero. Most likely the ethylene is a secondary product. This suggestion is in good agreement with the induction period in ethylene production, observed for Mg-modified catalyst, whose activity and rates of methanol and propylene production are lowest. As we showed earlier in [26], with an increase in temperature from 320 to $360{ }^{\circ} \mathrm{C}$, the selectivity of ethylene formation decreases, because the speed of the alkene cycle with increasing temperature increases faster than the arene rate. The equilibrium yield of methanol and the ratio of $\mathrm{C}_{2} \mathrm{H}_{4} / \mathrm{C}_{3} \mathrm{H}_{6}$ and $\mathrm{C}_{2} \mathrm{H}_{4} / \mathrm{C}_{4} \mathrm{H}_{8}$ were calculated to confirm our suggestion (Figure 7, Figure $\mathrm{S6}$, Figure 8).

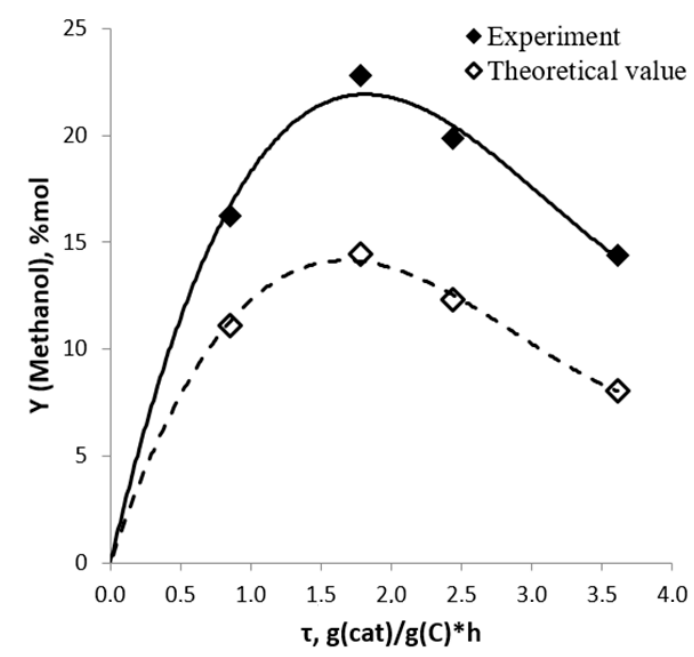

Figure 7. Yield of methanol $(\mathrm{Y}, \mathrm{mol} \%)$ as a function of specific contact time $\left(\tau, \mathrm{g}(\mathrm{cat}) / \mathrm{g}(\mathrm{C})^{*} \mathrm{~h}\right)$ for $\mathrm{Mg}-\mathrm{HZSM}-5 / \mathrm{Al}_{2} \mathrm{O}_{3}$. Experimental values are in solid line, theoretic values are in dashed line.

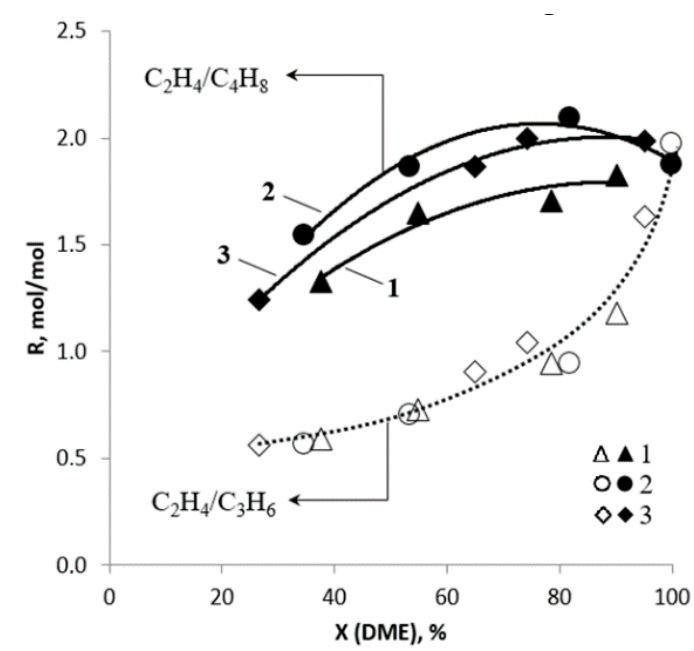

Figure 8. Molar ratio (R, mol/mol) as a function of DME conversion (X (DME), \%). 1- $\mathrm{HZSM}-5 / \mathrm{Al}_{2} \mathrm{O}_{3}$; 2-Zr-HZSM-5/ $/ \mathrm{Al}_{2} \mathrm{O}_{3} ; 3-\mathrm{Mg}-\mathrm{HZSM}-5 / \mathrm{Al}_{2} \mathrm{O}_{3} . \mathrm{C}_{2} \mathrm{H}_{4} / \mathrm{C}_{3} \mathrm{H}_{6}$-dashed line; $\mathrm{C}_{2} \mathrm{H}_{4} / \mathrm{C}_{4} \mathrm{H}_{8}$ - solid line.

To determine the theoretical methanol yield through the equilibrium constant and isobaric reaction potential relationship equation, we assumed that in a certain contact time DME converts to olefin and water, and the last reacts with unconverted DME and gives methanol. As seen from Figure 7 and Figure S6, the experimental yield of methanol is higher than the theoretical. This can indicate that the equilibrium of DME $\Leftrightarrow$ Methanol does not achieve the limit at the macromolecular level due to deviation of the system from ideality (because of the electrostatic interaction of intermediates with 
the inner surface of zeolite channels) or to an additional pathway for methanol formation. The same conclusion regarding the equilibrium was made by Olsbye et al. [53].

The ratio of $\mathrm{C}_{2} \mathrm{H}_{4} / \mathrm{C}_{3} \mathrm{H}_{6}$ (Figure 8, dashed line) for all samples increased from 0.5 to 2.0 with an increase of DME conversion in range of $25-100 \%$, suggesting that at low DME conversions the rate of propylene formation from the hydrocarbon pool is higher than of ethylene one. The rates of $C_{4}$ and $C_{5}$ hydrocarbons formation during methylation of propylene were much lower than for ethylene, and as a consequence, the ratios of $\mathrm{C}_{2} \mathrm{H}_{4} / \mathrm{C}_{4} \mathrm{H}_{8}$ (Figure 8, solid line) and $\mathrm{C}_{2} \mathrm{H}_{4} / \mathrm{C}_{5} \mathrm{H}_{10}$ (Figure S8) appeared higher. This is in accordance with the conclusions of $\mathrm{Ch}$. Wang et al. [54].

Hence, we have shown that for all samples the experimental points of the dependence of the each product selectivity on the conversion are described by the same curves. Metal introduction and the corresponding changes in the acid sites distribution do not change the ratio of main reaction rates. Only the absolute values of the formation rate of the products are changed.

To assess the effect of metal doping on the change in the rate of secondary reactions, we calculated the marks characterizing the isomerization and $\mathrm{H}$-transfer reactions-the ratio of iso-/n-alkenes and hydrogen transfer index.

Significant differences were observed only in the distribution of isomerization products (Figure 9 and Figure S9). As seen for HZSM-5/ $\mathrm{Al}_{2} \mathrm{O}_{3}$ and Mg-modified samples, the ratio of iso-/n for $\mathrm{C}_{4} \mathrm{H}_{8}$ does not depend on DME conversion and equals 0.08 . The higher isomerization ability of $\mathrm{Zr}$ results in redistribution of butenes towards a larger formation of iso- $\mathrm{C}_{4} \mathrm{H}_{8}$, and the ratio of iso- $/ \mathrm{n}-\mathrm{C}_{4} \mathrm{H}_{8}$ increases up to 0.19-0.21 (Figure 9A). The same pattern for $\mathrm{C}_{5} \mathrm{H}_{10}$, iso-/n, was observed (Figure 9B).

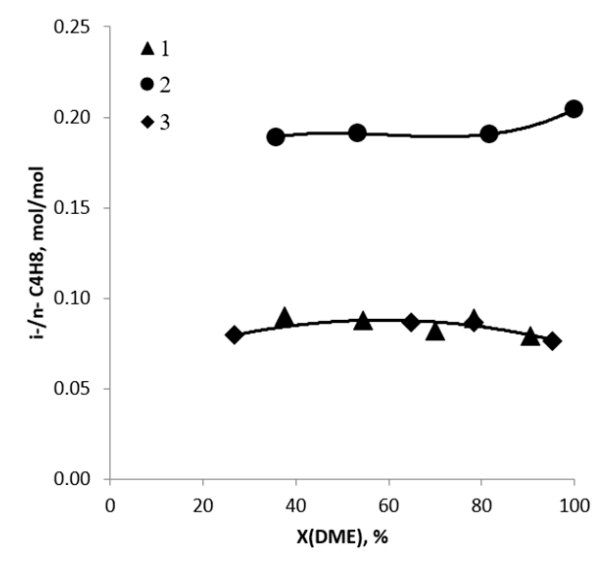

A)

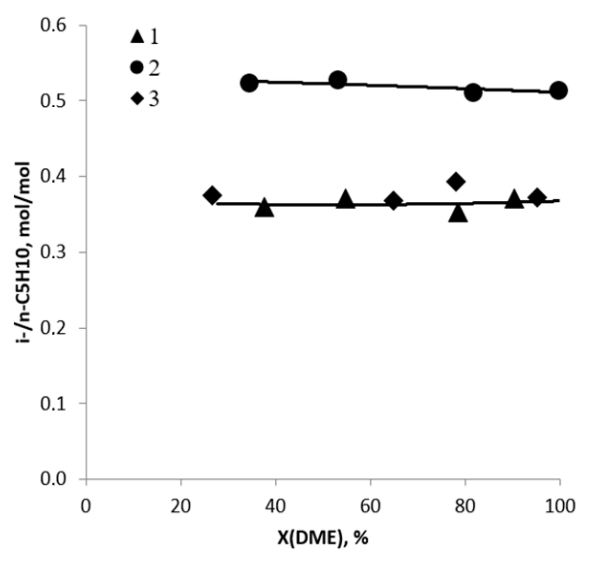

B)

Figure 9. Molar ratio of iso- $/ \mathrm{n}-\mathrm{C}_{4}-\mathrm{C}_{5}$ alkenes as a function of DME conversion (X (DME), \%). 1- $\mathrm{HZSM}-5 / \mathrm{Al}_{2} \mathrm{O}_{3} ; \quad 2-\mathrm{Zr}-\mathrm{HZSM}-5 / \mathrm{Al}_{2} \mathrm{O}_{3} ; 3-\mathrm{Mg}-\mathrm{HZSM}-5 / \mathrm{Al}_{2} \mathrm{O}_{3} . \quad$ (A) iso-/n-butenes; (B) iso-/n-pentenes.

To describe hydride transfer activity, the hydrogen transfer index (HTI) is used in methane-to-hydrocarbons (MTH) chemistry [7,53-55]. HTI is defined as the ratio of alkane molar concentration to the total hydrocarbon concentration with the same carbon number. HTI for $\mathrm{C}_{3}$ hydrocarbons is defined as the ratio of propane concentration to the sum of propylene and propane concentration. HTI for $\mathrm{C}_{4}$ hydrocarbons is defined as the ratio of butanes concentration to the sum of butenes and butanes concentration. Figure 10 shows $C_{3}$ and $C_{4}$ HTI as a function of DME conversion. 


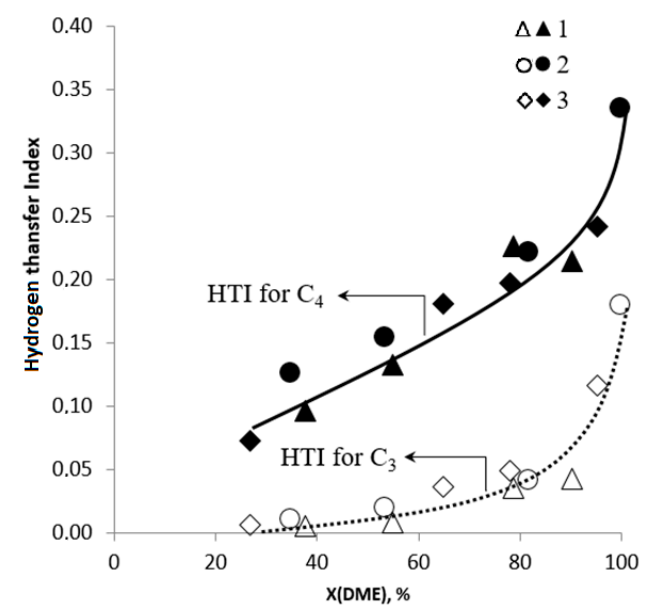

Figure 10. Hydrogen transfer index as a function of DME conversion (X (DME), \%). 1- $\mathrm{HZSM}-5 / \mathrm{Al}_{2} \mathrm{O}_{3}$; 2- Zr-HZSM-5/ $\mathrm{Al}_{2} \mathrm{O}_{3} ; 3-\mathrm{Mg}-\mathrm{HZSM}-5 / \mathrm{Al}_{2} \mathrm{O}_{3}$. HTI for $\mathrm{C}_{3}$ hydrocarbons-dashed line; HTI for $\mathrm{C}_{4}$ hydrocarbons—solid line.

One can see that the rate of hydride transfer increases with the DME conversion and experimental points can be described by the same curves for all samples. Here, the changes for $\mathrm{C}_{4} \mathrm{HTI}$ appear as more dynamic, indicating that the $\mathrm{H}$-transfer of $\mathrm{C}_{4}$ hydrocarbons to be faster than that for $\mathrm{C}_{3}$. Most likely, olefin formation and hydrogen transfers proceed in sequential reactions. It should be noted that the opposite results were obtained by Sun X. and Mueller S., who studied methanol conversion to olefin in the presence of water [21].

Hence, we have shown metal introduction change the activity of steady state catalysts that formed after hydrothermal treatment. The rate of DME conversion is decreasing in series $\mathrm{Zr}-\mathrm{HZSM}-5 / \mathrm{Al}_{2} \mathrm{O}_{3}>$ $\mathrm{HZSM}-5 / \mathrm{Al}_{2} \mathrm{O}_{3}>\mathrm{Mg}-\mathrm{HZSM}-5 / \mathrm{Al}_{2} \mathrm{O}_{3}$. So the activity of hydrothermal treatment catalyst is determined mainly by acidity. According to the TPD $\mathrm{NH}_{3}$ data, $\mathrm{Zr}$ leads to the formation of acid sites, in which the adsorption-desorption stage with the formation of carbocations occurs faster. On the other hand, the introduction of $\mathrm{Mg}$ and the formation on the surface of weak acid sites like $\mathrm{Mg}-\mathrm{OH}^{+}$significantly reduce the rate of carbocations formation. The metal introduction do not change the main route for the product formation at atmospheric pressure for steady state catalysts and the chemistry of reaction is determined mainly by the zeolite structure $[53,56,57]$. Inside the zeolite channels of different topologies, transition states stabilize for various reactions. A closer pore size in the zeolite and transition state lead to a more stable complex [56]. For example, zeolites of type HBEA and FAU are characterized by stabilization of bimolecular transition states of methylation and H-transfer, but iso-structure compounds are formed mainly due to secondary reactions, for example, $\beta$-scissor of high molecular compounds [58-60]. In the pores of SAPO, aromatization and alkylation/dealkylation of arenes most rapidly occur. Inside narrow pores of MFI zeolite, a monomolecular dialkyl cyclopropane-like transition state is stabilized, which, therefore, has the highest probability of isomerization reactions $[61,62]$. However, the nature of the metal can affect the rate of secondary reactions, such as isomerization. We have shown that the introduction of zirconium leads to an increase in the fraction of iso-alkenes in the products.

\subsection{Routes of Olefin Formation from DME over Steady-State Catalyst}

Based on experimental observations, the modified mechanism of olefin formation from DME over steady-state catalyst that synthesizes using hydrothermal treatment can be proposed. The main reactions, taking place in the system at different conversions, can be presented by Scheme 1. 


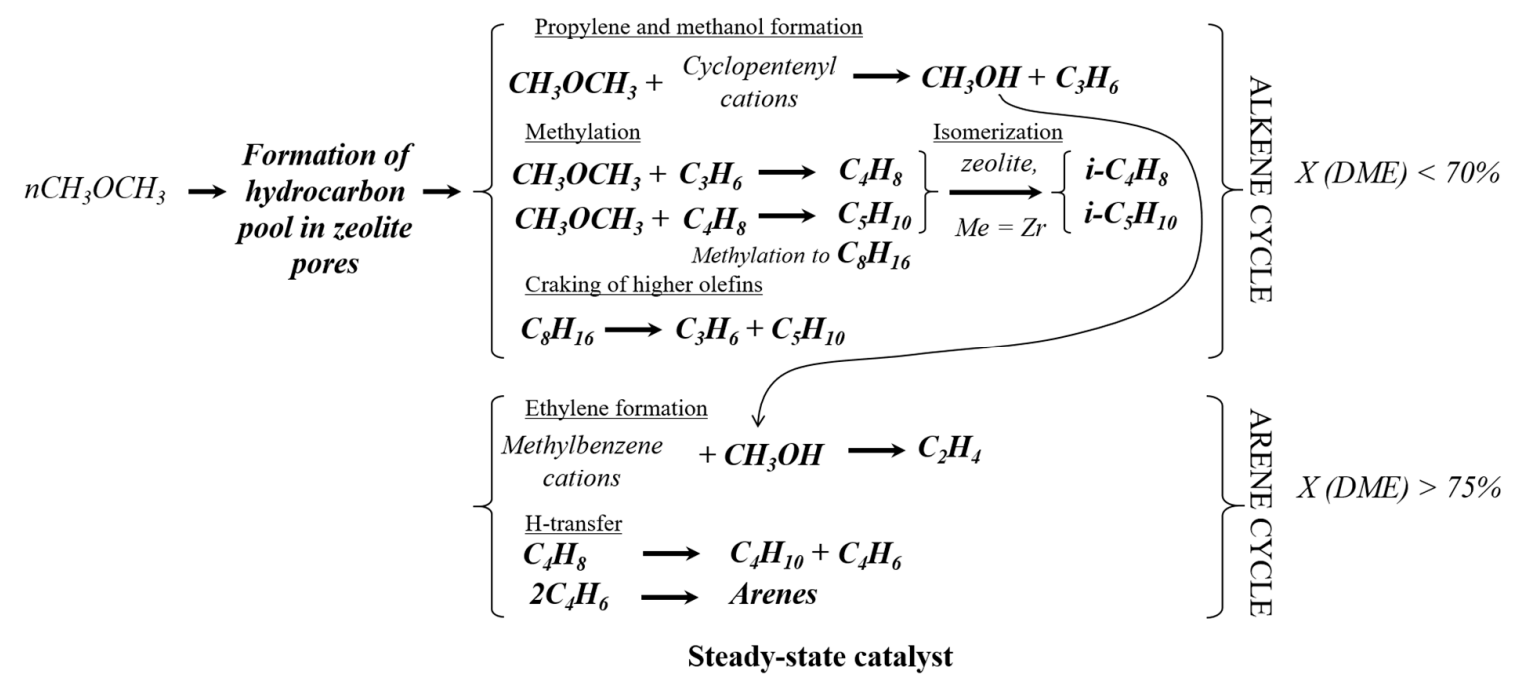

Scheme 1. Reactions during of olefin synthesis from DME over steady-state catalyst.

At the surface of steady-state catalyst the hydrocarbon pool is already formed. This includes both alkenes (formed from cyclopentenyl cations) [54,63,64] and arene (methylbenzenes cations) species [29] that can participate in lower olefin formation. The significance of the species on the steady-state catalyst for product formation is dependent on the concentration of DME and mechanisms for methanol and propylene formation are related, especially at low conversions of DME. There is an alternative route for methanol formation not only from DME hydrolysis, but also during methylation by DME in alkene cycle.

At moderate raw material conversion $(<70 \%)$, the rate of alkene cycle over steady state catalyst is probably very high. DME reacts with alkene species, resulting in methanol and propylene formation by simultaneous mechanisms. The direct formation of propylene from surface methoxy species and DME was evidence on H-ZSM-5 zeolite by isotopic studies of IR observation of surface species and GC-mass analysis of product by Yamazaki H. and co-wokers [65].

Methanol selectivity does not depend on temperature [26]; it is determined only by DME conversion and pressure. Propylene undergoes methylation by DME preferable to form butenes. The activation energy of olefin $C_{2}-C_{4}$ methylation by dimethyl ether is $6-10 \mathrm{~kJ} / \mathrm{mol}$ lower than for methanol. So the methanol is accumulated in the system and its yield increases, since it is inferior in adsorption rates of DME. Higher olefin also formed during propylene oligomerization reactions. The higher olefin gives additional propylene and, to a lesser extent, ethylene by cracking on acid sites in the alkene cycle [19-21]. Thus, propylene is formed mostly in the alkene cycle and is the dominant product under low DME conversions when the ratio [DME]/[formed methanol] is high.

At high DME conversion ( $>75 \%$ ) and at lower ratio [DME]/[formed methanol], the last is actively involved in the reaction. Changes in the balance of DTO reactions in dual-cycle mechanism are observed with more ethylene formation and domination of aromatic cycle. For aromatic compounds, the activation energy of the methylation reaction by dimethyl ether is comparable to or exceeds the values for methanol [52,66-69] (see Table S3). Methanol mostly reacts with arene species, resulting in ethylene formation, which is confirmed by the studies with labeled carbon atoms [20,51,70-73]. The reaction of methanol with olefins or cyclopentyl cations proceeds slower than aromatic alkylation, and the rate of olefin formation in the arene cycle is increased. Ethylene is not subjected to secondary transformations because of high activation energy for methylation reactions and its yield increases. This explains why ethylene production has an induction period and the selectivity on propylene is lower and the ratio propylene/ethylene is decreased at high DME conversion. The hydrogen transfer reactions on the zeolite acid sites are also pronounced with alkane formation. More detailed chemical reaction equations are presented in Table S4. 
Thus, the proposed simultaneous mechanism does not contradict the concept of 'dual cycle' in the part of product secondary reactions, but rather defines a route for the first products' formation on the steady-state catalyst at low DME conversion

\section{Experimental}

\subsection{Catalyst Preparation}

Initial HZSM- 5 with $\mathrm{SiO}_{2} / \mathrm{Al}_{2} \mathrm{O}_{3}=37$ for catalyst production was purchased from the Catalysts and Organic Synthesis Production Plant in Angarsk (Angarsk, Russia). $42.7 \mathrm{~g}$ of $\mathrm{AlO}(\mathrm{OH})$ (JSC Promcatalys, Ryazan, Russia) were placed in a mixer and $20 \mathrm{~mL}$ of a peptizing solution ( $5 \mathrm{~mL}$ of $\mathrm{HNO}_{3}$ (JSC Base 1 Chemicals, Kupavna, Russia) $+15 \mathrm{~mL}$ of $\mathrm{H}_{2} \mathrm{O}$ ) were added. The mixture was stirred for $5 \mathrm{~min}$. Added $76.5 \mathrm{~g}$ of dry zeolite HZSM-5. The mass was stirred for $20 \mathrm{~min}$ at $60^{\circ} \mathrm{C}$ ). After that, the catalytic mass was passed through an extruder with a die diameter of $3 \mathrm{~mm}$. The finished extrudates $\mathrm{HZSM}-5 / \mathrm{Al}_{2} \mathrm{O}_{3}$ were dried in air for $12 \mathrm{~h}$, then in a drying oven at $110-150{ }^{\circ} \mathrm{C}$ for $4 \mathrm{~h}$, and calcined at $500{ }^{\circ} \mathrm{C}$ for $4 \mathrm{~h}$. During calcination $\mathrm{AlO}(\mathrm{OH})$ is converted to $\mathrm{Al}_{2} \mathrm{O}_{3}$. The final content of $\mathrm{Al}_{2} \mathrm{O}_{3}$ in the material obtained was $33 \mathrm{wt} \%$ Hutchings et al. [74] showed that $\mathrm{Al}_{2} \mathrm{O}_{3}$ exhibits low activity in the synthesis of hydrocarbons. However, when used for the preparation of the zeolite catalyst pseudo-boehmite, followed by calcining, the catalyst can slightly increase the selectivity of the propylene formation [10]. Since the synthesis of extrudates (zeolite $+\mathrm{AlO}(\mathrm{OH})$ ) was carried out in the same way and the content of $\mathrm{Al}_{2} \mathrm{O}_{3}$ in all of the samples does not change, in the present work it is considered only as a binder to increase the mechanical strength of the catalyst particles.

These fabricated extrudates of $\mathrm{HZSM}-5 / \mathrm{Al}_{2} \mathrm{O}_{3}$ were modified metals. $100 \mathrm{~g}$ of catalyst were filled with a solution of $\mathrm{Mg}\left(\mathrm{NO}_{3}\right)_{2} \cdot 6 \mathrm{H}_{2} \mathrm{O}(\mathrm{m}=10.55 \mathrm{~g}$ ) (JSC Base 1 Chemicals, Kupavna, Russia) or $\mathrm{Zr}\left(\mathrm{NO}_{3}\right)_{2} \cdot 2 \mathrm{H}_{2} \mathrm{O}(\mathrm{m}=2.76 \mathrm{~g})$ (JSC Base 1 Chemicals, Kupavna, Russia) with a volume of $105 \mathrm{~mL}$ for $1 \mathrm{~h}$. Next, the catalyst was dried at a temperature of $110-150{ }^{\circ} \mathrm{C}$ for $4 \mathrm{~h}$, and calcined at a temperature of $500{ }^{\circ} \mathrm{C}$ for $4 \mathrm{~h}$. The $\mathrm{NH}_{3}$ desorption profiles of the HZSM-5/ $\mathrm{Al}_{2} \mathrm{O}_{3}, \mathrm{Zr}$ - and Mg-modified fresh samples are shown in Figure S1. The estimated amount of $\mathrm{Zr}$ and $\mathrm{Mg}$ in samples was $1.0 \mathrm{wt} \%$

All samples were hydrothermally treated before catalytic experiments at $500{ }^{\circ} \mathrm{C}$ for $6 \mathrm{~h}$ at WHSV of steam $12 \mathrm{~h}^{-1}$. The detailed description of catalyst preparation method could be found in the patents $[75,76]$.

\subsection{Catalyst Characterization}

The metal loading was determined by X-ray fluorescence analysis on the ARL PERFORM'X Sequential XFR (Thermo Fisher Scientific, Atkinson, NH, USA) equipped with the rhodium tube $(3.5 \mathrm{~kW})$.

X-ray powder diffraction (XRD) patterns of samples were recorded on a Rigaku Rotaflex RU-200 diffractometer with $\mathrm{Cu} \mathrm{K} \mathrm{K}_{\alpha}$ radiation $(1.5418 \AA, 50 \mathrm{kV}$ and $160 \mathrm{~mA})$. The relative crystallinity was determined by comparing the peak area in the range of $2 \theta$ from 22 to $25^{\circ}$ of modified samples with initial HZSM-5 $/ \mathrm{Al}_{2} \mathrm{O}_{3}$, considered to have $100 \%$ crystallinity.

${ }^{27} \mathrm{Al}$ MAS NMR spectra recorded on the $11.7 \mathrm{~T}$ Varian Unity Inova $500 \mathrm{MHz}$ spectrometer (Mettler Tolledo, Columbus, OH, USA). The samples were placed in a T3 HXY sensor (3.2 mm) rotating at a frequency of $15 \mathrm{kHz}$. The operating frequencies for ${ }^{27} \mathrm{Al}$ were $130.3 \mathrm{MHz}$. The interval between scans was $0.5 \mathrm{~s}$, and the number of scans was 4000 . Chemical shifts were calibrated with $1 \mathrm{M}$ aqueous solution of $\mathrm{AlCl}_{3}$.

Specific surface area and pore volume were determined from $\mathrm{N}_{2}$ adsorption/desorption isotherms at $-196^{\circ} \mathrm{C}$ on ASAP $2010 \mathrm{~N}$ instrument (Micromeritics, Norcross, GA, USA). Prior to measurement, catalyst samples were degassed under high vacuum at $350{ }^{\circ} \mathrm{C}$ for $6 \mathrm{~h}$.

The amount, strength and distribution of acid sites were determined by $\mathrm{NH}_{3}-\mathrm{TPD}$ on a chemical adsorption analyzer USGA (Moscow, Russia) with a thermal conductivity detector. All samples ( $0.15 \mathrm{~g}$ ) before measurements were pretreated by heating in a helium flow at $500^{\circ} \mathrm{C}$ (heating rate of $20^{\circ} \mathrm{C} / \mathrm{min}$ ), 
calcination at $500^{\circ} \mathrm{C}$ for $1 \mathrm{~h}$ and cooling to $60^{\circ} \mathrm{C}$. Then, samples were saturated with $\mathrm{NH}_{3}$ for $15 \mathrm{~min}$, flushed with helium at $100{ }^{\circ} \mathrm{C}$ for $1 \mathrm{~h}$ to remove physically adsorbed $\mathrm{NH}_{3}$ and cooled to $60{ }^{\circ} \mathrm{C}$. Final desorption of $\mathrm{NH}_{3}$ was performed at $60-750{ }^{\circ} \mathrm{C}$ at a heating rate of $8{ }^{\circ} \mathrm{C} / \mathrm{min}$ in helium flow.

Pyridine adsorption infrared spectra were obtained using a Nicolet iS10 (Thermo Fisher Scientific, Atkinson, NH, USA)) FTIR spectrometer with an MCT detector in $4000-400 \mathrm{~cm}^{-1}$ region with a resolution of $4 \mathrm{~cm}^{-1}$. Before measurements, samples were dehydrated at $400{ }^{\circ} \mathrm{C}$ for $1 \mathrm{~h}$ under a vacuum of $10^{-4} \mathrm{~Pa}$. The adsorption of pyridine was performed at $150^{\circ} \mathrm{C}$ for $10 \mathrm{~min}$. The system was evacuated at $150{ }^{\circ} \mathrm{C}$ for $30 \mathrm{~min}$ and the IR spectra were recorded. Acidity was calculated using the OMNIC ESP software package version 7.2 (Thermo Fisher Scientific, Atkinson, NH, USA, 2015). The Brönsted/Lewis ratio (B/L) was determined as the ratio of band areas at 1545 and $1455 \mathrm{~cm}^{-1}$. The molar extinction coefficient of $1545 \mathrm{~cm}^{-1}$ band was $1.26 \mathrm{~cm} / \mu \mathrm{mol}$.

\subsection{Catalytic Tests}

Catalytic experiments were performed in a fixed-bed continuous flow quartz reactor with an inner diameter of $10 \mathrm{~mm}$ at atmospheric pressure and $320^{\circ} \mathrm{C}$. Here catalyst, weighing $0.5-1.0 \mathrm{~g}$ $\left(\mathrm{d}_{\mathrm{p}}=0.4-0.63 \mathrm{~mm}\right)$, was mixed with quartz $\left(\mathrm{d}_{\mathrm{p}}=0.5-1.0 \mathrm{~mm}\right)$ with the volume ratio of $1: 1$. Prior to the experiment, the catalyst was preheated and purged with nitrogen flow at $400{ }^{\circ} \mathrm{C}$ for $1 \mathrm{~h}$ to remove physically adsorbed water. The dimethyl ether/nitrogen mixture with a concentration of DME of $10-13 \mathrm{vol} \%$ was used as a feedstock. The GHSV was varied in the range of $2500-25,000 \mathrm{~h}^{-1}$. For these conditions ( $\left.\mathrm{d}_{\mathrm{p}}, \mathrm{GHSV}\right)$, the influence of external and internal diffusion was not observed [38]. The experimental results for the stable-state catalysts that observed after $1 \mathrm{~h}$ of time on the stream are presented in Figure S2.

The reaction products were analysed using an on-line gas chromatograph (Crystallux-4000M) equipped with a flame ionization detector (FID) and a thermal conductivity detector (TCD). The capillary column with the CP-Poraplot $Q$ phase $(27.5 \mathrm{~m} \times 0.32 \mathrm{~mm} \times 10 \mu \mathrm{m})$ was used to determine the composition of hydrocarbons $\mathrm{C}_{1}-\mathrm{C}_{8}$, methanol, and DME. The packed column with a Porapak $Q$ phase $(3.0 \mathrm{~m} \times 4 \mathrm{~mm} \times 3 \mu \mathrm{m})$ was used to determine $\mathrm{N}_{2}$. The analysis was performed at the programmed temperature increase from $90-250{ }^{\circ} \mathrm{C}$ with a heating rate of $30^{\circ} \mathrm{C} / \mathrm{min}$, and the carrier gas was helium. Chromatograms were processed using the NetChromWin software (Version 2.0, JSC Scientific Production Company Meta-Chrome, Yoshkar-Ola, Russia, 2017) and hardware systems.

The reaction products observed were methanol, alkenes $C_{2}-C_{4}$, alkanes $C_{1}-C_{4}$, and hydrocarbons $\mathrm{C}_{5}-\mathrm{C}_{8}$ (alkanes, cyclo-, and aromatic compounds). The specific contact time per carbon for DME $(\tau)$ varied from $0.2-3.2 \mathrm{~g}(\mathrm{cat}) / \mathrm{g}(\mathrm{C})^{*} \mathrm{~h}$, corresponding to DME conversion in the range of $20-95 \%$. The results averaged over three parallel measurements with a relative error of $5-7 \%$ were used for calculation of catalytic activity.

\subsection{Catalytic Performances}

The conversion of DME, selectivity, and yield of products was calculated from the Equations

$$
\begin{gathered}
X(\text { DME })=[n(\text { DME in })-n(\text { DME out })] / n(\text { DME in }) \times 100, \% ; \\
S_{i}=n(C i) / \Sigma n(\text { Ci . . m }) \times 100, \text { mol. \%; } \\
Y_{i}=n(C i) / n(\text { DME in }) \times 100, \text { mol. \%; }
\end{gathered}
$$

where $\mathrm{n}(\mathrm{Ci})$ is mole of $i$ carbon containing compound in products at the reactor outlet, mole; $\Sigma \mathrm{n}(\mathrm{Ci} \ldots$ $\mathrm{m})$ is the sum of moles of products at the reactor outlet, mole; $i \ldots m$ are carbon containing compounds (alkanes $\mathrm{C}_{1}-\mathrm{C}_{4}$, methanol, olefins $\mathrm{C}_{2}-\mathrm{C}_{4}$, hydrocarbons $\mathrm{C}_{5}-\mathrm{C}_{8}$ ); $\mathrm{n}$ (DME in), $\mathrm{n}$ (DME out) are moles of DME at the reactor inlet and outlet, mole. 
As a parameter, contact time is calculated based on carbon, which will allow long-term comparison of the results when using any carbon-containing raw materials (DME, methanol, mixture methanol or DME), in any modes of the reaction (flow, flow-circulation).

$$
\tau=\mathrm{m}(\text { cat }) / \mathrm{G}(\mathrm{C}(\mathrm{DME})), \mathrm{g}(\mathrm{cat}) \cdot \mathrm{h} / \mathrm{g}(\mathrm{C}),
$$

where $\mathrm{m}($ cat $)$ is mass of catalyst, $\mathrm{g} ; \mathrm{G}(\mathrm{C}(\mathrm{DME}))$ is mass flow of carbon in DME at the reactor inlet, $\mathrm{g}(\mathrm{C}) / \mathrm{h}$.

The contact time per DME can be calculated as multiplication of $\tau$ and factor $M(D M E) / 2 * M(C)$, where $\mathrm{M}$ is the molecular mass of DME and carbon, $\mathrm{g} / \mathrm{mol}$.

The main results of investigation are represented as a functions of $X(D M E)=f(\tau), Y(C i)=f(\tau)$, $\mathrm{S}(\mathrm{Ci})=\mathrm{f}(\mathrm{X}(\mathrm{DME}))$.

\section{Conclusions}

Kinetic studies of olefin synthesis based on $\mathrm{HZSM}-5 / \mathrm{Al}_{2} \mathrm{O}_{3}$, as well as $\mathrm{HZSM}-5 / \mathrm{Al}_{2} \mathrm{O}_{3}$, modified by $\mathrm{Zr}$ and $\mathrm{Mg}$ and stabilized by hydrothermal treatment were performed. The metal was found to influence sample acidity, determining the catalyst activity at steady state. At high initial total acidity, the activity of the Mg-modified sample was lowest; at the same time it was highest for $\mathrm{Zr}$-modified sample with low total acidity. Changes in product selectivity for $\mathrm{HZSM}-5 / \mathrm{Al}_{2} \mathrm{O}_{3}, \mathrm{Zr}$-, and Mg-modified samples were similar and did not depend on catalyst acidity. Hence, the metal did not affect the way of transformations of the intermediates, and the main routes of product formation were similar for all samples. For all catalysts, the same changing the balance of the DTO reaction in dual-cycle mechanism from alkene to aromatic cycle with the rise of DME conversion and with accumulation of methanol is observed. It was shown that methanol and propylene formed simultaneously from DME in the alkene cycle mechanism under low DME conversion. At high DME conversions, the arene cycle with methanol as alkylated agent became more important and there was an increase in the ethylene fraction in the reaction products.

At the same time, the nature of the metal influenced the DME conversion rate and higher hydrocarbons isomer distribution; the portion of branched isomers was higher for the Zr-modified sample.

The results of this paper can be used to develop a detailed kinetic model of an industrial reactor in which the properties of the catalyst are close to the properties of a stable catalyst, which was studied in this work; such a model also allows us to consider the changes in the ratio of reaction rates over a wide range of DME conversions.

Supplementary Materials: The following are available online at http://www.mdpi.com/2073-4344/9/5/485/s1, Figure S1: $\mathrm{NH}_{3}$ TPD profiles of the fresh $\mathrm{HZSM}-5 / \mathrm{Al}_{2} \mathrm{O}_{3}, \mathrm{Zr}$ - and $\mathrm{Mg}$-modified samples; Figure S2. Conversion of $\mathrm{DME}\left(\mathrm{X}(\mathrm{DME})\right.$ ) as a function of time on stream (TOS); Figure S3. 27Al MAS NMR spectra of Mg-HZSM-5/ $\mathrm{Al}_{2} \mathrm{O}_{3}$. 3-hydrothermally treated sample, 3S-fresh sample; Figure S4. The pore size distribution (A) (BJH method) and BET isotherms (B); Figure S5. IR spectra of pyridine adsorbed at $150{ }^{\circ} \mathrm{C}$; Figure S6. The experimental and equilibrium yield of methanol for HZSM-5/ $\mathrm{Al}_{2} \mathrm{O}_{3}(\mathrm{~A})$ and $\mathrm{Zr}-\mathrm{HZSM}-5 / \mathrm{Al}_{2} \mathrm{O}_{3}$ (B); Figure S7. The product distribution of $\mathrm{C} 1-\mathrm{C} 4$ alkanes (A) and C5-C8 hydrocarbons (B) over Mg-HZSM-5/ $\mathrm{Al}_{2} \mathrm{O}_{3}$; Figure S8. The ratio of ethylene/alkenes C3-C5 $(\mathrm{R})$ as a function of DME conversion (X(DME)) for the Mg-HZSM-5/ $\mathrm{Al}_{2} \mathrm{O}_{3}$; Figure S9. Molar ratio of trans-/cis$\mathrm{C}_{4} \mathrm{H}_{8}$ as a function of DME conversion (X(DME)); Table S1. Unit cell parameters for $\mathrm{HZSM}-5 / \mathrm{Al}_{2} \mathrm{O}_{3}$ material and $\mathrm{Zr}$ - and Mg-modified samples; Table S2. Products distribution for $\mathrm{HZSM}-5 / \mathrm{Al}_{2} \mathrm{O}_{3}, \mathrm{Zr}$-, and Mg- modified samples. Experimental data; Table S3. The activation energy for the methylation reaction of olefins $\mathrm{C} 2-\mathrm{C} 4$ and aromatics. Zeolite HZSM-5 $\left(\mathrm{SiO}_{2} / \mathrm{Al}_{2} \mathrm{O}_{3}=45\right)$. Experimental data; Table S4. Chemical reaction equations of conversion DME into hydrocarbons.

Author Contributions: Conceptualization, A.M.; Data curation, E.G.; Formal analysis, E.G. and M.A.; Investigation, I.D.; Methodology, I.D.; Project administration, A.M.; Supervision, M.M.; Validation, M.M.; Visualization, M.A.; Writing—original draft, M.M.; Writing—review \& editing, A.M.

Funding: This work was financially supported by the Russian Science Foundation (grant No. 17-73-30046). 
Acknowledgments: This work was financially supported by the Russian Science Foundation (Grant No 17-73-30046). The authors are grateful for the help of Kolyagin Yu.G. and Smirnov A.V. (MSU, Chemistry faculty, Department of Physical Chemistry), as well as Sorokin S.E. and Levin I.S. (TIPS RAS, Department of Physical and Chemical Investigations). This paper is dedicated to memory of Salambek Khadzhiev, our Chief and the Founder of the Zeolite Catalysis School in Russia.

Conflicts of Interest: The authors declare no conflict of interest.

\section{References}

1. Stocker, M. Methanol-to-hydrocarbons: Catalytic Materials and their behavior. Microporous Mesoporous Mater. 1999, 29, 3. [CrossRef]

2. Niu, X.; Gao, J.; Wang, K.; Miao, Q.; Dong, M.; Wang, G.; Fan, W.; Qin, Z.; Wang, J. Influence of crystal size on the catalytic performance of H-ZSM-5 and Zn/H-ZSM-5 in the conversion of methanol to aromatics. Fuel Process. Technol. 2017, 157, 99. [CrossRef]

3. Lee, K.-Y.; Lee, H.-K.; Ihm, S.-K. Influence of catalyst binders on the acidity and catalytic performance of hzsm-5 zeolites for methanol-to-propylene (MTP) process: Single and binary binder system. Top. Catal. 2010, 53, 247. [CrossRef]

4. Michels, N.; Mitchell, S.; Pérez-Ramírez, J. Effects of binders on the performance of shaped hierarchical MFI zeolites in methanol-to-hydrocarbons. ACS Catal. 2014, 4, 2409. [CrossRef]

5. Ong, L.H.; Dömök, M.; Olindo, R.; Veen, A.C.; Lercher, J.A. Dealumination of HZSM-5 via steam-treatment. Microporous Mesoporous Mater. 2012, 164, 9. [CrossRef]

6. Almutairi, S.M.T.; Mezari, B.; Pidko, E.A.; Magusin, P.C.M.M.; Hensen, E.J.M. Influence of steaming on the acidity and the methanol conversion reaction of HZSM-5 zeolite. J. Catal. 2013, 307, 194. [CrossRef]

7. Zhang, S.; Gong, Y.; Zhang, L.; Liu, Y.; Dou, T.; Xu, J.; Deng, F. Hydrothermal treatment on ZSM-5 extrudates catalyst for methanol to propylene reaction: Finely tuning the acidic property. Fuel Process. Technol. 2015, 129, 130. [CrossRef]

8. Kim, H.; Jang, H.-G.; Jang, E.; Park, S.J.; Lee, T.; Jeong, Y.; Baik, H.; Cho, S.J.; Choi, J. On methanol to hydrocarbons reactions in a hierarchically structured ZSM-5 zeolite catalyst. Catal. Today 2018, 303, 150. [CrossRef]

9. Al-Dughaither, A.S.; de Lasa, H. Neat dimethyl ether conversion to olefins (DTO) over HZSM-5: Effect of $\mathrm{SiO}_{2} / \mathrm{Al}_{2} \mathrm{O}_{3}$ on porosity, surface chemistry, and reactivity. Fuel 2014, 138, 52. [CrossRef]

10. Pérez-Uriarte, P.; Gamero, M.; Ateka, A.; Díaz, M.; Aguayo, A.T.; Bilbao, J. Effect of the acidity of HZSM-5 zeolite and the binder in the DME transformation to olefins. Ind. Eng. Chem. Res. 2016, 55, 1513. [CrossRef]

11. Hajjar, Z.; Khodadadi, A.; Mortazavi, Y.; Tayyebi, S.; Soltanali, S. Artificial intelligence modeling of DME conversion to gasoline and light olefins over modified nano ZSM-5 catalysts. Fuel 2016, 179, 79. [CrossRef]

12. Fujiwara, M.; Mimura, N.; Sato, O.; Yamaguchi, A. Surface modification of HZSM-5 with organo-disilane compound for propylene production from dimethyl ether. Microporous Mesoporous Mater. 2019, $280,219$. [CrossRef]

13. Park, S.; Watanabe, Y.; Nishita, Y.; Fukuoka, T.; Inagaki, S.; Kubota, Y. Catalytic conversion of dimethyl ether into propylene over MCM-68 zeolite. J. Catal. 2014, 319, 265. [CrossRef]

14. Ahmed, M.H.M.; Muraza, O.; Al-Amer, A.M.; Miyake, K.; Nishiyama, N. Development of hierarchical EU-1 zeolite by sequential alkaline and acid treatments for selective dimethyl ether to propylene (DTP). Appl. Catal. A Gen. 2015, 497, 127. [CrossRef]

15. Zhang, S.H.; Zhang, B.L.; Gao, Z.X.; Han, Y.Z. Methanol to olefin over Ca-modified HZSM-5 zeolites. Ind. Eng. Chem. Res. 2010, 49, 2103. [CrossRef]

16. Bakare, I.A.; Muraza, O.; Sanhoob, M.A.; Miyake, K.; Hirota, Y.; Yamani, Z.H.; Nishiyama, N. Dimethyl ether-to-olefins over aluminum rich ZSM-5: The role of Ca and La as modifiers. Fuel 2018, 211, 18. [CrossRef]

17. Xu, A.; Ma, H.; Zhang, H.; Ying, W.; Fang, D. Effect of boron on ZSM-5 catalyst for methanol to propylene conversion. Pol. J. Chem. Technol. 2013, 15, 95. [CrossRef]

18. Barros, Z.S.; Zotin, F.M.Z.; Henriques, C.A. Conversion of natural gas to higher valued products: Light olefins production from methanol over ZSM-5 zeolites. Stud. Surf. Sci. Catal. 2007, 167, 255.

19. Bjørgen, M.; Svelle, S.; Joensen, F.; Nerlov, J.; Kolboe, S.; Bonino, F.; Palumbo, L.; Bordiga, S.; Olsbye, U. Conversion of methanol to hydrocarbons over zeolite H-ZSM-5: On the origin of the olefinic species. J. Catal. 2007, 249, 195. [CrossRef] 
20. Olsbye, U.; Svelle, S.; Bjørgen, M.; Beato, P.; Janssens, T.V.W.; Joensen, F.; Bordiga, S.; Lillerud, K.P. Conversion of methanol to hydrocarbons: How zeolite cavity and pore size controls product selectivity. Angew. Chem. Int. Ed. 2012, 51, 5810. [CrossRef]

21. Sun, X.; Mueller, S.; Liu, Y.; Shi, H.; Haller, G.L.; Sanchez-Sanchez, M.; van Veen, A.C.; Lercher, J.A. On reaction pathways in the conversion of methanol to hydrocarbons on HZSM-5. J. Catal. 2014, 317, 185. [CrossRef]

22. Zhu, Q.; Kondo, J.N.; Setoyama, T.; Yamaguchi, M.; Domenc, K.; Tatsumi, T. Activation of hydrocarbons on acidic zeolites: Superior selectivity of methylation of ethene with methanol to propene on weakly acidic catalysts. Chem Comm 2008, 41, 5164. [CrossRef]

23. Wei, R.; Li, C.; Yang, C.; Shan, H. Effects of ammonium exchange and Si/Al ratio on the conversion of methanol to propylene over a novel and large partical size ZSM-5. J. Nat. Gas. Chem. 2011, 20, 261. [CrossRef]

24. Ilias, S.; Khare, R.; Malek, A.; Bhan, A. A descriptor for the relative propagation of the aromatic- and olefin-based cycles in methanol-to-hydrocarbons conversion on H-ZSM-5. J. Catal. 2013, 303, 135. [CrossRef]

25. Wu, W.; Guo, W.; Xiao, W.; Luo, M. Methanol conversion to olefins (MTO) over H-ZSM-5: Evidence of product distribution governed by methanol conversion. Fuel Process. Technol. 2013, 108, 19. [CrossRef]

26. Magomedova, M.V.; Peresypkina, E.G.; Davydov, I.A.; Khadzhiev, S.N. Olefin synthesis from dimethyl ether in the presence of a hydrothermally treated $\mathrm{Mg}-\mathrm{HZSM}-5 / \mathrm{Al}_{2} \mathrm{O}_{3}$ catalyst: Effect of reaction conditions on the product composition and ratio. Petrol. Chem. 2017, 57, 1043. [CrossRef]

27. Guo, W.; Wu, W.; Luo, M.; Xiao, W. Modeling of diffusion and reaction in monolithic catalysts for the methanol-to-propylene process. Fuel Process. Technol. 2013, 108, 133. [CrossRef]

28. Ortega, C.; Hessel, V.; Kolb, G. Dimethyl ether to hydrocarbons over ZSM-5: Kinetic study in an external recycle reactor. Chem. Eng. J. 2018, 354, 21. [CrossRef]

29. Yaripour, F.; Shariatinia, Z.; Sahebdelfar, S.; Irandoukht, A. Effect of boron incorporation on the structure, products selectivities and lifetime of H-ZSM-5 nanocatalyst designed for application in methanol-to-olefins (MTO) reaction. Microporous Mesoporous Mater. 2015, 203, 41. [CrossRef]

30. Song, Y.; Zhang, L.; Li, G.; Shang, Y.; Zhao, X.; Ma, T.; Zhang, L.; Zhai, Y.; Gong, Y.; Xu, J.; et al. ZSM-5 extrudates modified with phosphorus as a super effective MTP catalyst: Impact of the acidity on binder. Fuel Process. Technol. 2017, 168, 105. [CrossRef]

31. Rostamizadeh, M.; Taeb, A. Highly selective Me-ZSM-5 catalyst for methanol to propylene (MTP). J. Ind. Eng. Chem. 2015, 27, 297. [CrossRef]

32. Goryainova, T.I.; Biryukova, E.N.; Kolesnichenko, N.V.; Khadzhiev, S.N. Study of magnesium-containing zeolite catalysts for the synthesis of lower olefins from dimethyl ether. Petrol. Chem. 2011, 51, 169. [CrossRef]

33. Long, X.; Zhang, Q.; Liu, Z.-T.; Qi, P.; Lu, J.; Liu, Z.W. Magnesia modified H-ZSM-5 as an efficient acidic catalyst for steam reforming of dimethyl ether. Appl. Catal. B Environ. 2013, 134-135, 381. [CrossRef]

34. Sano, T.; Kiyozumi, Y.; Shin, S. Synthesis of light olefins from methanol using ZSM-5 type zeolite catalysts. Sekiyu Gakkaishi 1992, 35, 429. [CrossRef]

35. Biryukova, E.N.; Goryainova, T.I.; Kulumbegov, R.V.; Kolesnichenko, N.V.; Khadzhiev, S.N. Conversion of dimethyl ether into lower olefins on a La-Zr-HZSM-5/ $\mathrm{Al}_{2} \mathrm{O}_{3}$ zeolite catalyst. Petrol. Chem. 2011, 51, 49. [CrossRef]

36. Zhao, T.-S.; Takemoto, T.; Tsubaki, N. Direct synthesis of propylene and light olefins from dimethyl ether catalyzed by modified H-ZSM-5. Catal. Comm. 2006, 7, 647. [CrossRef]

37. Vedrine, J.C.; Auroux, A.; Dejaifve, P.; Ducarme, V.; Hoser, H.; Zhou, S. Catalytic and physical properties of phosphorus-modified ZSM-5 zeolite. J. Catal. 1982, 73, 147. [CrossRef]

38. Afokin, M.I.; Davydov, I.A.; Galanova, E.G.; Magomedova, M.V. The structure and stability of the Mg-HZSM-5/ $\mathrm{Al}_{2} \mathrm{O}_{3}$ catalyst for synthesis of olefins from DME: The influence of thermal and hydrothermal treatment. Catal. Ind. 2019, 19, 50. [CrossRef]

39. Kumar, S.; Sinha, A.K.; Hegde, S.G.; Sivasanker, S. Influence of mild dealumination on physicochemical, acidicand catalytic properties of H-ZSM-5. J. Mol. Catal. A Chem. 2000, 154, 115. [CrossRef]

40. Jin, L.; Hu, H.; Wang, X.; Liu, C. Methylation of 2-methylnaphthalene with methanol to 2,6-dimethylnaphthalene over ZSM-5 modified by Zr and Si. Ind. Eng. Chem. Res. 2006, 45, 3531. [CrossRef] 
41. Bjørgen, M.; Joensen, F.; Spangsberg Holm, M.; Olsbye, U.; Lillerud, K.; Svelle, S. Methanol to Gasoline over zeolite H-ZSM-5: Improved catalyst performance by treatment with NaOH. Appl. Catal. A Gen. 2008, 345, 43. [CrossRef]

42. Chen, C.; Zhang, Q.; Meng, Z.; Li, C.; Shan, H. Effect of magnesium modification over H-ZSM-5 in methanol to propylene reaction. Appl. Petrochem. Res. 2015, 5, 277. [CrossRef]

43. Li, X.; Jiang, X. Propylene oligomerization to produce diesel fuel on Zr-ZSM-5 catalyst. Chem. Tech. Fuel Oils 2013, 49, 156. [CrossRef]

44. Mao, D.; Yang, W.; Xia, J.; Zhang, B.; Song, Q.; Chen, Q. Highly effective hybrid catalyst for the direct synthesis of dimethyl ether from syngas with magnesium oxide-modified HZSM-5 as a dehydration component. J. Catal. 2005, 230, 140. [CrossRef]

45. Graça, I.; Iruretagoyena, D.; Chadwick, D. Glucose isomerisation into fructose over magnesium-impregnated NaY zeolite catalysts. Appl. Catal. B Environ. 2017, 206, 434. [CrossRef]

46. Di Cosimo, J.I.; Díez, V.K.; Ferretti, C.; Apesteguía, C.R. Basic catalysis on MgO: Generation, characterization and catalytic properties of active sites. Catalysis 2014, 26, 1.

47. Graça, I.; Bacariza, M.C.; Fernandes, A.; Chadwick, D. Desilicated NaY zeolites impregnated with magnesium as catalysts for glucose isomerisation into fructose. Appl. Catal. B Environ. 2018, 224, 660. [CrossRef]

48. Barbera, K.; Bonino, F.; Bordiga, S.; Janssens, T.V.W.; Beato, P. Structure-deactivation relationship for ZSM-5 catalysts governed by framework defects. J. Catal. 2011, 280, 196. [CrossRef]

49. Chang, C.D.; Silvestri, A.J. The conversion of methanol and other O-compounds to hydrocarbons over zeolite catalysts. J. Catal. 1977, 47, 249. [CrossRef]

50. Perez-Uriarte, P.; Ateka, A.; Aguayo, A.T.; Gayubo, A.G.; Bilbao, J. Kinetic model for the reaction of DME to olefins over a HZSM-5 zeolite catalyst. Chem. Eng. J. 2016, 302, 801. [CrossRef]

51. Svelle, S.; Rønning, P.O.; Olsbye, U.; Kolboe, S. Kinetic studies of zeolite-catalyzed methylation reactions. Part 2. co-reaction of $\left[{ }^{12} \mathrm{C}\right]$ propene or $\left[{ }^{12} \mathrm{C}\right]$ n-butene and $\left[{ }^{13} \mathrm{C}\right]$ methanol. J. Catal. 2005, 234, 385. [CrossRef]

52. Hill, I.M.; Hashimi, S.A.; Bhan, A. Kinetics and mechanism of olefin methylation reactions on zeolites. J. Catal. 2012, 285, 115. [CrossRef]

53. Martinez-Espin, J.S.; Marten, M.; Janssens, T.V.W.; Svelle, S.; Beato, P.; Olsbye, U. New insights into catalyst deactivation and product distribution of zeolites in the methanol-to-hydrocarbons (MTH) reaction with methanol and dimethyl ether feeds. Catal. Sci. Technol. 2017, 7, 2700. [CrossRef]

54. Wang, C.; Sun, X.; Xu, J.; Qi, G.; Wang, W.; Zhao, X.; Li, W.; Wang, Q.; Deng, F. Impact of temporal and spatial distribution of hydrocarbon pool on methanol conversion over H-ZSM-5. J. Catal. 2017, 354, 138. [CrossRef]

55. Wei, Z.; Chen, L.; Cao, Q.; Wen, Z.; Zhou, Z.; Xu, Y.; Zhu, X. Steamed Zn/ZSM-5 catalysts for improved methanol aromatization with high stability. Fuel Process. Technol. 2017, 162, 66. [CrossRef]

56. Simonetti, D.A.; Carr, R.T.; Iglesia, E. Acid strength and solvation effects on methylation, hydride transfer, and isomerization rates during catalytic homologation of $C_{1}$ species. J. Catal. 2012, 285, 19. [CrossRef]

57. Yarulina, I.; Goetze, J.; Gücüyener, C.; Thiel, L.; Dikhtiarenko, A.; Ruiz-Martinez, J.; Weckhuysen, B.M.; Gascon, J.; Kapteijna, F. Methanol-to-olefins process over zeolite catalysts with DDR topology: Effect of composition and structural defects on catalytic performance. Catal. Sci. Technol. 2016, 6, 2663. [CrossRef]

58. Simonetti, D.A.; Ahn, J.H.; Iglesia, E. Mechanistic details of acid-catalyzed reactions and their role in selective synthesis of triptane and isobutene from dimethyl ether. J. Catal. 2011, 277, 173. [CrossRef]

59. Svelle, S.; Arstad, B.; Kolboe, S.; Swang, O. A theoretical investigation of the methylation of alkenes with methanol over acidic zeolites. J. Phys. Chem. B 2003, 107, 9281. [CrossRef]

60. Svelle, S.; Tuma, C.; Rozanska, X.; Kerber, T.; Sauer, J. Quantum chemical modeling of zeolite-catalyzed methylation reactions: Toward chemical accuracy for barriers. J. Am. Chem. Soc. 2009, 131, 816. [CrossRef] [PubMed]

61. Natal-Santiago, M.A.; Alcala, R.; Dumesic, J.A. DFT study of the isomerization of hexyl species involved in the acid-catalyzed conversion of 2-methyl-pentene-2. J. Catal. 1999, 181, 124. [CrossRef]

62. Frash, M.V.; Kazanzky, V.B.; Rigby, A.M.; van-Santen, R.A. Density functional and hartree-fock calculations on the cyclopropane ring intermediates involved in the zeolite-catalyzed skeletal isomerization of hydrocarbons and in the carbon isotope scrambling in 2-propyl cation. J. Phys. Chem. B 1997, 101, 5346. [CrossRef]

63. Haw, J.F.; Nicholas, J.B.; Song, W.; Deng, F.; Wang, Z.; Xu, T.; Heneghan, C.S. Roles for cyclopentenyl cations in the synthesis of hydrocarbons from methanol on zeolite catalyst HZSM-5. J. Am. Chem. Soc. 2000, 122, 4763. [CrossRef] 
64. Wang, C.; Chu, Y.; Zheng, A.; Xu, J.; Wang, Q.; Gao, P.; Qi, G.; Gong, Y.; Deng, F. New insight into the hydrocarbon-pool chemistry of the methanol-to-olefins conversion over zeolite H-ZSM-5 from GCMS, solid-state NMR spectroscopy, and DFT calculations. Chem. Eur. J. 2014, 20, 12432. [CrossRef]

65. Yamazaki, H.; Shima, H.; Imai, H.; Yokoi, T.; Tatsumi, T.; Kondo, J.N. Direct production of propene from methoxy species and dimethyl ether over H-ZSM-5. J. Phys. Chem. C 2012, 116, 24091. [CrossRef]

66. Svelle, S.; Kolboe, S.; Swang, O.; Olsbye, U. Methylation of alkenes and methylbenzenes by dimethyl ether or methanol on acidic zeolites. J. Phys. Chem. B 2005, 109, 12874. [CrossRef]

67. Svelle, S.; Visur, M.; Olsbye, U.; Bjørgen, M. Mechanistic aspects of the zeolite catalyzed methylation of alkenes and aromatics with methanol: A review. Top. Catal. 2011, 54, 897. [CrossRef]

68. Rabiu, S.; Al-Khattaf, S. Kinetics of toluene methylation over ZSM-5 catalyst in a riser simulator. Ind. Eng. Chem. Res. 2008, 47, 39. [CrossRef]

69. Hill, I.; Malek, A.; Bhan, A. Kinetics and mechanism of benzene, toluene, and xylene methylation over H-MFI. ACS Catal. 2013, 3, 1992. [CrossRef]

70. Lesthaeghe, D.; De Sterck, B.; Van Speybroeck, V.; Marin, G.B.; Waroquier, M. Zeolite shape-selectivity in the gem-methylation of aromatic hydrocarbons. Angew. Chem. Int. Ed. 2007, 46, 1311. [CrossRef]

71. Svelle, S.; Rønning, P.O.; Kolboe, S. Kinetic studies of zeolite-catalyzed methylation reactions 1. Coreaction of $\left[{ }^{12} \mathrm{C}\right]$ ethene and $\left[{ }^{13} \mathrm{C}\right]$ methanol. J. Catal. 2004, 224, 115. [CrossRef]

72. Bjørgen, M.; Joensen, F.; Lillerud, K.; Olsbye, U.; Svelle, S. The mechanisms of ethene and propene formation from methanol over high silica H-ZSM-5 and H-beta. Catal. Today 2009, 142, 90. [CrossRef]

73. Hutchings, G.J.; Rensburg, L.J.; Pick, W.; Hunter, R. Hydrocarbon formation from methanol and dimethyl ether using $\mathrm{WO}_{3} / \mathrm{Al}_{2} \mathrm{O}_{3}$ and H-ZSM-5 catalysts. J. Chem. Soc. Faraday Trans. I 1988, 84, 1311. [CrossRef]

74. Ilias, S.; Bhan, A. Tuning the selectivity of methanol-to-hydrocarbons conversion on H-ZSM-5 by co-processing olefin or aromatic compounds. J. Catal. 2012, 290, 186. [CrossRef]

75. TIPS RAS, JSC ELINP. Catalyst and Method for Olefins Synthesis from Dimethyl Ether in Its Presence. Patent RU 2445158, 2012.

76. TIPS RAS. Catalyst and Method for Olefins Synthesis from Dimethyl Ether in Its Presence. RU 2323777, 2008.

(C) 2019 by the authors. Licensee MDPI, Basel, Switzerland. This article is an open access article distributed under the terms and conditions of the Creative Commons Attribution (CC BY) license (http://creativecommons.org/licenses/by/4.0/). 